\title{
Modelling phytoplankton succession and nutrient transfer along the Scheldt estuary (Belgium, The Netherlands)
}

\author{
N. Gypens ${ }^{\text {a,* }}$, E. Delhez ${ }^{\text {b }}$, A. Vanhoutte-Brunier ${ }^{\text {a,c }}$, S. Burton ${ }^{\text {b }}$, V. Thieu ${ }^{\text {d,e }}$, P. Passy ${ }^{\text {d }}$, Y. Liu ${ }^{\text {a,f }}{ }^{\text {, J. Callens }}{ }^{\text {d }}$, \\ V. Rousseau ${ }^{a}$, C. Lancelot $^{\mathrm{a}}$ \\ a Université Libre de Bruxelles, Ecologie des Systèmes Aquatiques, CP-221, Bd du Triomphe, B-1050, Belgium \\ ${ }^{\mathrm{b}}$ Université de Liège, MARE, Modélisation et Méthodes Mathématiques, Sart-Tilman B37, B-4000 Liège, Belgium \\ c Ifremer, UMR Amure, Département d'Economie Maritime, BP 70, F-29280 Plouzané, France \\ d Université Pierre et Marie Curie, UMR 7619 Sisyphe, 4 Place Jussieu, F-75005 Paris, France \\ e Joint Research Centre of the European Commission, Ispra, Italy \\ ${ }^{\mathrm{f}}$ Yantai Institute of Coastal Zone Research, Chinese Academy of Sciences, Yantai, China, 264003, PR China
}

\section{A R T I C L E I N F O}

\section{Article history:}

Received 8 December 2011

Received in revised form 8 October 2012

Accepted 9 October 2012

Available online 17 October 2012

\section{Keywords:}

Scheldt estuary

Coupled river-marine model

Phytoplankton succession

Nutrient export

\begin{abstract}
A B S T R A C T
The freshwater (RIVE) and the marine (MIRO) biogeochemical models were coupled to a 1D hydrosedimentary model to describe contemporary phytoplankton succession and nutrient transfers in the macrotidal Scheldt estuary (BE/NL) affected by anthropogenic nutrient loads. The 1D-RIVE-MIRO model simulations are performed between Ghent and Vlissingen and the longitudinal estuarine profiles are validated by visual and statistical comparison with physico-chemical and phytoplankton observations available for the year 2006. Results show the occurrence of two distinct spatial phytoplankton blooms in the upper and lower estuary, suggesting that neither the freshwater nor the marine phytoplankton gets over the maximum turbidity zone (MTZ) at the saline transition. Sensitivity tests performed to understand how changing conditions (salinity, turbidity and nutrients) along the estuary are controlling this bimodal spatial phytoplankton distribution identify salinity and light availability as the key drivers while the grazing pressure and nutrient limitation play a negligible role. Additional tests with varying salinity-resistant (euryhaline) species in the freshwater assemblage conclude that the presence (or absence) of euryhalines determines the magnitude and the spreading of freshwater and marine phytoplankton blooms in the estuary. Annual nutrient budgets estimated from 1D-RIVE-MIRO simulations show that biological activities have a negligible impact on nutrient export but modify the speciation of nutrients exported to the coastal zone towards inorganic forms, thus directly available to phytoplankton. The implementation of nutrient reduction options (upgrading of waste water treatment plants, conversion to organic farming) on the Scheldt watershed influences the whole estuary and affects both the magnitude and the speciation of nutrients exported to the coastal zone with expected impact on coastal phytoplankton dynamic.
\end{abstract}

(C) 2012 Elsevier B.V. All rights reserved.

\section{Introduction}

Estuaries are shallow open systems strongly influenced by river inputs, mixing with the coastal ocean and exchanges across the sediment-water and atmosphere-water interfaces. These transitional zones between the freshwater and the marine systems are characterised by important salinity (SAL) gradients and receive large amounts of dissolved and particulate carbon (C), nitrogen $(\mathrm{N})$, phosphorus (P) and silicon ( $\mathrm{Si}$ ) of natural and anthropogenic origin from rivers. This riverine material undergoes profound transformations in estuaries before being transferred to the adjacent coastal zone (Wollast, 1983). Under the dual influence of climate and anthropogenic changes (e.g. Paerl et al., 2006), estuaries are characterised by

\footnotetext{
* Corresponding author. Tel.: + 32 26505990; fax: + 3226505993.

E-mail address: ngypens@ulb.ac.be (N. Gypens).
}

a large variability of physical and chemical properties that affect directly planktonic communities and indirectly the biogeochemical role of estuaries, in terms of e.g. transformation, retention or removal of nutrients.

At the interface between freshwater and marine ecosystems, estuaries are characterised by distinct phytoplankton assemblages along the salinity gradient (Attrill and Rundle, 2002; Muylaert et al., 2009; Quinlan and Philips, 2007). While freshwater phytoplankton is adapted to low salinity and marine species to high salinity, some species are resistant to small salinity fluctuations and grow at intermediate salinity (e.g. Muylaert et al., 2009; Roubeix et al., 2008). In addition to the impact of salinity, the mixing of fresh and marine waters creates unique hydrodynamic and hydro-sedimentary conditions (in particular water residence time and turbidity) that structure the estuarine ecosystem and impact the associated carbon and nutrient cycles (Lancelot and Muylaert, 2012). Understanding the effect of 
these physico-chemical conditions on phytoplankton organisms and describing the phytoplankton succession is a pre-requisite to assessing the ecological and biogeochemical function of estuaries.

The Scheldt estuary, located in the southwest Netherlands and northern Belgium (Fig. 1), is a shallow, well-mixed, and relatively turbid macrotidal estuary. It is one of the most nutrient-rich and polluted systems in the world (Wollast, 1988) where human activities on the watershed have deeply altered the quality of surface waters since the second half of the 20th century (Billen et al., 2005; Meire et al., 2005; Soetaert et al., 2006; Van Damme et al., 2005). Increased river nutrient and organic matter inputs have changed the estuarine biological activities and biogeochemical cycles (Billen et al., 2005; Soetaert et al., 2006) and have contributed to the eutrophication of the coastal waters of the Southern North Sea (e.g. Lancelot et al., 2007). Since the 1990's the implementation of wastewater treatment led to a marked improvement in the water quality in the estuary (Soetaert and Herman, 1995a; Soetaert et al., 2006). In particular, the largest wastewater treatment plant of the city of Brussels (1.4 M inhabitant equivalent IE) is operating since March 2007. Phytoplankton communities are spatially structured in the Scheldt estuary with marked shifts between freshwater, euryhaline and marine species (Lancelot and Muylaert, 2012; Muylaert et al., 2000). Despite important changes in nutrient concentration, primary production in the Scheldt estuary does not seem to have changed significantly with nutrient load modification (Gazeau et al., 2005; Kromkamp and Peene, 2005). Although the recent improvement of dissolved oxygen concentrations in the estuary had modified the importance and the composition of zooplankton organisms (e.g. Appeltans et al., 2003; Mialet et al., 2011) with an impact on the phytoplankton biomass (Kromkamp and Van Engeland, 2010).

Over the last two decades, several physical-biogeochemical models have been implemented in the Scheldt estuary for estimating the nutrient export to the coastal zone (Arndt et al., 2007; Hofmann et al., 2008; Regnier et al., 1997; Soetaert and Herman, 1995a,b; Vanderborght et al., $2002,2007)$. The description of the biological processes in these estuarine models is generally simple (based on total primary production) and the estuary is often considered as a unidirectional land-ocean transition. However, global change also affects the functioning of the coastal ocean and subsequently impacts the lower estuary. The adjacent coastal sea has been explicitly considered in a few Scheldt estuary models (Arndt et al., 2007; Vanderborght et al., 2007) but these were constrained by observed concentrations at the upper boundary of the estuary. A step further then consists in implementing high resolution coupled physical-biogeochemical models of the whole river-estuaryocean system for describing the effect of changing climate and human pressure on estuarine communities and related biogeochemical processes. Such models exist for the river drainage basin, the estuary and the adjacent coastal sea and have been partially coupled (e.g. Cugier et al., 2005) in an offline mode (e.g. Arndt et al., 2011; Lancelot et al., 2007). For instances, the marine biogeochemical MIRO model (Lancelot et al., 2005) was recently implemented in a fully transient two-dimensional, nested-grid hydrodynamic model of the Scheldt estuary and adjacent near-shore coastal zone continuum to quantify biogeochemical transformations and carbon and nutrients fluxes exported to the coastal zone (Arndt et al., 2011). This application allowed to estimate the importance of coastal intrusion in the estuary and to quantify the biogeochemical transformations and fluxes of $C$ and nutrients in the lower estuary. However, the explicit description of the freshwater community was missing in this model as only freshwater diatoms were imposed at the upper estuarine boundary and an artificial threshold allowed the shift between freshwater and marine diatoms.

In this study, we coupled the river (RIVE) and the marine (MIRO) ecologically-based biogeochemical models to describe contemporary plankton succession and the associated nutrient transformation, retention and removal in the Scheldt estuary and to estimate the nutrient export to the coastal zone. For this application the resulting RIVE-MIRO model is coupled with a one-dimensional hydrodynamic model of the Scheldt estuary that includes a suspended sediment module. The offline coupling with the marine 3D-MIRO\&CO model (Lacroix et al., 2007) of the Southern North Sea and the Seneque-Riverstrahler, a biogeochemical model of the Scheldt river system associated to a geographical information system (GIS) description of the watershed (Ruelland et al., 2007), provides respectively the marine, upper estuary and lateral tributary boundary conditions. To the best of our knowledge, this paper is the first attempt to use a river-estuary-coastal sea model that describes explicitly the fate of both freshwater and marine plankton species in the Scheldt estuary and their impact on the nutrient cycling and delivery to the sea. The ability of the model to reproduce biogeochemical trends in the Scheldt estuary is statistically appraised based on a comparison of model simulations with available observations in 2006. Sensitivity tests are further conducted to understand how changing conditions (salinity, turbidity and nutrients) along the estuary drive the spatial distribution of phytoplankton assemblages. Due to the high pressure of human activity on the Scheldt watershed, the coupled model is also

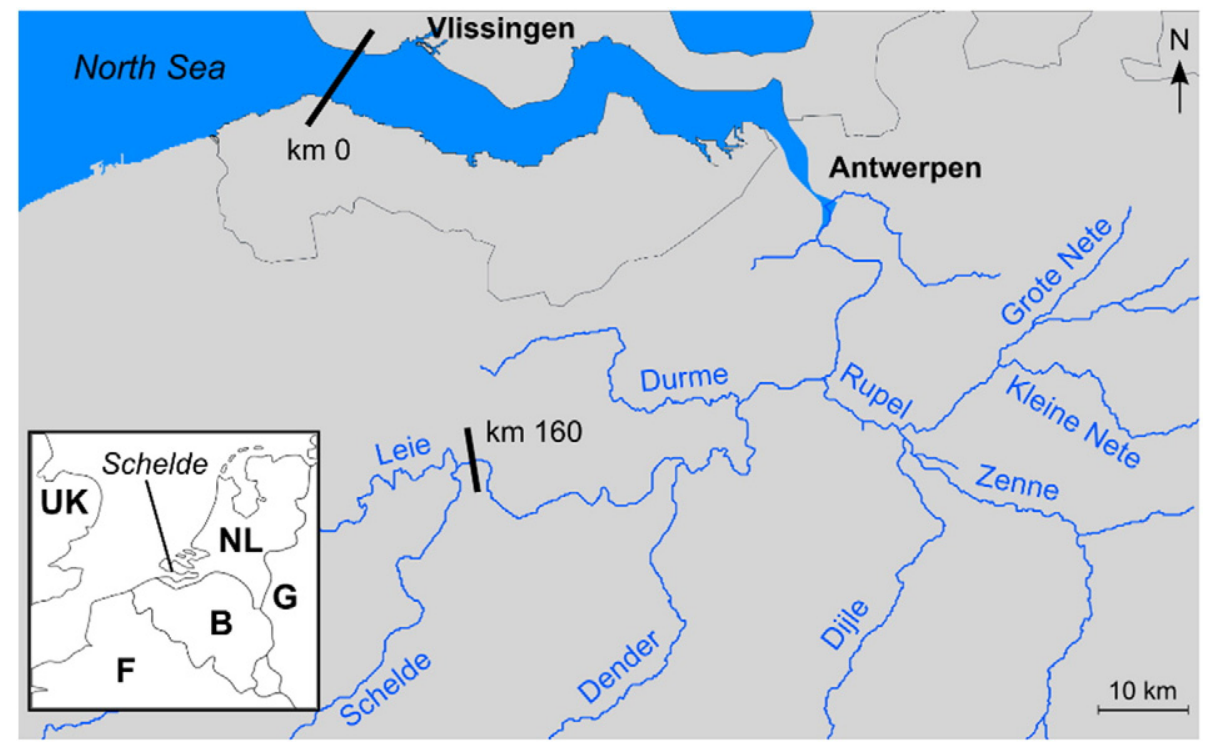

Fig. 1. River network of the 1D RIVE-MIRO model. $\mathrm{km} 0$ and $\mathrm{km} 160$ are giving the limit of the model domain. 
used to test the effect of nutrient reduction options (upgrading of waste water, change in agricultural practices) on the nutrient export and eutrophication status of the coastal zone.

\section{Material and methods}

The 1D-RIVE-MIRO results from the coupling between a 1D-hydrodynamic model of the Scheldt estuary, a sediment transport model and a complex biogeochemical model describing $C$ and nutrient ( $\mathrm{N}, \mathrm{P}$ and $\mathrm{Si}$ ) cycles in water and sediment.

\subsection{Hydro-sedimentary model}

The Scheldt river (350 km length) and its tributaries drain a mostly urban and agricultural basin of 21,500 $\mathrm{km}^{2}$ (with 540 inhabitants $\mathrm{km}^{-2}$ ) in northwestern France, northern Belgium and southwestern Netherlands. The model domain covers the Scheldt estuary $(160 \mathrm{~km}$ length), from Ghent to the mouth, at Vlissingen, where the Scheldt flows into the North Sea (Fig. 1). The area includes (i) the tidal river (the part of the Scheldt where the flow is influenced by tides), from Ghent to the confluence of the Scheldt with the Rupel near Rupelmonde, (ii) the brackish-marine part from Rupelmonde to Vlissingen and (iii) the major tributaries (Rupel, Durme, Dender, Nete, Dijle and Zenne) (Fig. 1). The width of the estuary is about $65 \mathrm{~m}$ near Ghent, $450 \mathrm{~m}$ at Antwerp and increases up to $5 \mathrm{~km}$ at the mouth (Vlissingen). The mean depth varies from about $14 \mathrm{~m}$ at the mouth (Vlissingen) to $7 \mathrm{~m}$ near Ghent (Soetaert and Herman, 1995b), some $160 \mathrm{~km}$ upstream.

The hydrodynamics is described by means of a 1D river network model based on the continuity and momentum equations integrated over the cross-section of the river:

$$
\begin{aligned}
& \frac{\partial A}{\partial t}+\frac{\partial Q}{\partial s}=0 \\
& \frac{\partial Q}{\partial t}+\frac{\partial}{\partial s}\left(\frac{Q Q}{A}\right)=-A g \frac{\partial \zeta}{\partial s}-g L \frac{Q|Q|}{A^{2} Y^{2}}
\end{aligned}
$$

where $t$ is the time, $s$ is the longitudinal coordinate, $A$ is the crosssection of the river segment, $L$ is the width of the river, $Q$ is the flow rate, $g$ is the gravitational acceleration, $\zeta$ is the free-surface and $Y$ is the Manning coefficient. In this approach, baroclinic processes are neglected as well as the curvature of the river channels. These effects are assumed to be small in the Scheldt and have also been neglected in similar previous model studies of the Scheldt (Regnier et al., 1997, 1998).

The model is solved numerically on a 1D grid with a spatial resolution of $2 \mathrm{~km}$. The equations are integrated forward in time using an explicit Euler scheme with a time step of $20 \mathrm{~s}$. Only the friction term is processed in an implicit way. Different spatial distributions of the Manning coefficient are used for the flood and ebb regimes. These are obtained from the calibration of the model against observed tidal heights (Laforce et al., 1977).

The dynamics of dissolved and suspended constituents is included in the same formalism according to

$$
\frac{\partial(A C)}{\partial t}+\frac{\partial}{\partial s}(Q C)=\frac{\partial}{\partial s}\left(A K \frac{\partial C}{\partial s}\right)+L J_{b o t}+A R
$$

where $C$ is the concentration of the constituent, $K$ is the longitudinal diffusion coefficient, $J_{b o t}$ is the net flux from the bottom and $R$ is the rate of production/destruction of the constituent. The longitudinal diffusion coefficient varies along the estuary between $75 \mathrm{~m}^{2} / \mathrm{s}$ and $450 \mathrm{~m}^{2} / \mathrm{s}$ and was calibrated against observed salinity measurements for the year 2000. One such equation is considered for each of the biogeochemical state variables of the model.
A TVD (Total Variation Diminishing) numerical scheme with Superbee limiter is used for the advection of scalar quantities (e.g. Hirsch, 1990; LeVeque, 1992; Toro, 1997). This scheme is second order accurate in smooth parts of the solution and avoids therefore the introduction of excessive numerical diffusion. In regions where rapid variations of the curvature are expected, the scheme reduces to a monotonic upwind scheme to avoid artificial oscillations and overshootings. As a result, the scheme appears as both robust and reliable since it produces physically meaningful solutions.

The advection-diffusion part of Eq. (3) is integrated forward in time with a time step of 5 min while the reaction terms are updated every 15 min only.

The model explicitly describes the dynamics of suspended matter (SPM), which largely controls the penetration of light in the water column and, hence, the primary production. The module (details in Delhez and Wolk, 2012) includes two classes of sediments (fine and coarse sediments) that are transported by the simulated current, can settle on the bottom when the bottom friction is lower than a critical value and be re-suspended when the critical stress is exceeded. The bottom consists in a layer of freshly deposited material that can be easily eroded and a parent consolidated layer that can only be eroded during more energetic hydrodynamic events (spring tide, storm surge). The sediment module was validated for the year 2000 , by comparison with available SPM data. This showed the model skill to correctly reproduce the mean level and the timing and amplitude of the SPM oscillations (Delhez and Wolk, 2012).

\subsection{Biogeochemical model RIVE-MIRO}

Two existing biogeochemical models - the freshwater RIVE (Garnier et al., 2002) and the marine MIRO (Lancelot et al., 2005) are combined to describe the dynamics of the biogenic elements in the Scheldt estuary and of the assemblage of freshwater and marine organisms. The numerical coupling of RIVE and MIRO is possible because of the structural similarity of the two models (Lancelot et al., 2007). All the state variables and the processes have been retained with only few adaptations. These include the pooling of organic carbon and inorganic and organic nutrients of freshwater and marine origin made available for both communities, the crossed trophic relations linking freshwater and marine preys and predators and the parameterization of the salinity effect on freshwater and marine organisms.

The coupled biogeochemical RIVE-MIRO model describes C, oxygen $\left(\mathrm{O}_{2}\right)$ and $\mathrm{N}, \mathrm{P}$ and $\mathrm{Si}$ cycles with an explicit description of freshwater and marines species. It includes 64 state variables (Table 1) describing the dynamics of phytoplankton, zooplankton, organic matter degradation and nutrient (nitrate $\left(\mathrm{NO}_{3}^{-}\right)$, ammonium $\left(\mathrm{NH}_{4}^{+}\right)$, dissolved silicate $\mathrm{DSi}\left(\mathrm{Si}(\mathrm{OH})_{4}\right)$ and phosphate $\left(\mathrm{PO}_{4}^{3-}\right)$ ) regeneration by bacteria in the water column and the sediment (Fig. 2). The RIVE-MIRO equations and parameters are fully documented in supplementary material.

The biological structure of the RIVE-MIRO model assembles fourteen plankton functional types (PFTs) including six phytoplankton groups, four zooplankton and four bacterioplankton groups (Table 1, Fig. 2). The phytoplankton module considers 6 phytoplankton groups: marine diatoms (DAm), marine nanoflagellates (NFm), the Haptophycea Phaeocystis (OPm), freshwater diatoms (DAr), Chlorophyceae (GRr) and cyanobacteria (Cyr). Phytoplankton growth is described considering 3 intracellular constituents (small metabolites (S), reserve material (R, [OPM]), functional and structural metabolites (F)) (Table 1) and distinguishes different processes: photosynthesis, reserve synthesis and catabolism, growth and associated nutrient uptake, respiration and lysis (Lancelot et al., 1991, 2005). The zooplankton module details the dynamics of 4 groups of zooplankton: marine microzooplankton (Mzm), rotifers (MZr) and marine ( $\mathrm{CPm}$ ) and freshwater (CPr) mesozooplankton. Trophic relations were established to link freshwater and marine preys 
Table 1

State variables of the RIVE-MIRO model.

\begin{tabular}{|c|c|}
\hline Variable & Symbol \\
\hline \multicolumn{2}{|l|}{ Biological state variable } \\
\hline \multicolumn{2}{|l|}{ 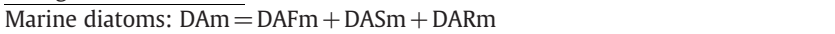 } \\
\hline Functional and structural metabolites & DAFm \\
\hline Monomers & DASm \\
\hline Reserves & DARm \\
\hline \multicolumn{2}{|l|}{ Marine nanoflagellates: NFm $=\mathrm{NFFm}+\mathrm{NFSm}+\mathrm{NFRm}$} \\
\hline Functional and structural metabolites & NFF \\
\hline Monomers & NFS \\
\hline Reserves & NFR \\
\hline \multicolumn{2}{|l|}{ Phaeocystis colonies: $\mathrm{OP}=\mathrm{OPF}+\mathrm{OPS}+\mathrm{OPR}+\mathrm{OPM}$} \\
\hline Functional and structural metabolites & OPF \\
\hline Monomers & OPS \\
\hline Reserves & OPR \\
\hline Mucous matrix & OPM \\
\hline \multicolumn{2}{|l|}{ Freshwater diatoms: $\mathrm{DAr}=\mathrm{DAFr}+\mathrm{DASr}+\mathrm{DARr}$} \\
\hline Functional and structural metabolites & DAFr \\
\hline Monomers & DASr \\
\hline Reserves & DARr \\
\hline \multicolumn{2}{|l|}{ Freshwater nanoflagellates: $\mathrm{GR}=\mathrm{GRF}+\mathrm{GRS}+\mathrm{GRR}$} \\
\hline Functional and structural metabolites & GRF \\
\hline Monomers & GRS \\
\hline Reserves & GRR \\
\hline \multicolumn{2}{|l|}{ Cyanobacteria: $\mathrm{CY}=\mathrm{CYF}+\mathrm{CYS}+\mathrm{CYR}$} \\
\hline Functional and structural metabolites & CYF \\
\hline Monomers & CYS \\
\hline Reserves & CYR \\
\hline Marine bacteria & $\mathrm{BC}$ \\
\hline Freshwater bacteria (small and large) & BAS,BAL \\
\hline Nitrifying bacteria & BAN \\
\hline Marine microzooplankton & $\mathrm{MZm}$ \\
\hline Rotifers & $\mathrm{MZr}$ \\
\hline Marine mesozooplankton & $\mathrm{CPm}$ \\
\hline Freshwater copepods & $\mathrm{CPr}$ \\
\hline \multicolumn{2}{|l|}{ Organic matter } \\
\hline Monomeric: carbon, nitrogen & BSC, BSN \\
\hline Dissolved polymers (high biodegradability): C,N,P & $\mathrm{DC}_{1}, \mathrm{DN}_{1}, \mathrm{DP}_{1}$ \\
\hline Dissolved polymers (low biodegradability): C,N,P & $\mathrm{DC}_{2}, \mathrm{DN}_{2}, \mathrm{DP}_{2}$ \\
\hline Dissolved polymers (refractory): C,N,P & $\mathrm{DC}_{3}, \mathrm{DN}_{3}, \mathrm{DP}_{3}$ \\
\hline Particulate organic matter (high biodegradability): C,N,P & $\mathrm{PC}_{1}, \mathrm{PN}_{1}, \mathrm{PP}_{1}$ \\
\hline Particulate organic matter (low biodegradability): C,N,P & $\mathrm{PC}_{2}, \mathrm{PN}_{2}, \mathrm{PP}_{2}$ \\
\hline Particulate organic matter (refractory): C,N,P & $\mathrm{PC}_{3}, \mathrm{PN}_{3}, \mathrm{PP}_{3}$ \\
\hline Detrital biogenic silica & $\mathrm{BSi}$ \\
\hline \multicolumn{2}{|l|}{ Inorganic nutrients } \\
\hline$\overline{\text { Nitrate }}$ & $\mathrm{NO}_{3}$ \\
\hline Ammonium & $\mathrm{NH}_{4}$ \\
\hline Total Inorganic phosphorus & PIT \\
\hline Phosphate & $\mathrm{PO}_{4}$ \\
\hline Dissolved silicate & DSi \\
\hline \multicolumn{2}{|l|}{ Benthic state variable } \\
\hline 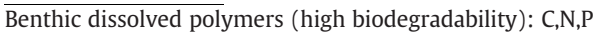 & $\mathrm{BC}_{1}, \mathrm{BN}_{1}, \mathrm{BP}_{1}$ \\
\hline Benthic dissolved polymers (low biodegradability): C,N,P & $\mathrm{BC}_{2}, \mathrm{BN}_{2}, \mathrm{BP}_{2}$ \\
\hline Benthic dissolved polymers (refractory): C,N,P & $\mathrm{BC}_{3}, \mathrm{BN}_{3}, \mathrm{BP}_{3}$ \\
\hline Benthic detrital biogenic silica & BBSi \\
\hline Benthic total inorganic phosphorus & BPIT \\
\hline
\end{tabular}

and predators (Fig. 2). As a first step, freshwater and marine preys are assumed to be available to all classes of zooplankton that however keep their specific prey preferences. Hence, marine nanoflagellates and Chlorophyceae are grazed by marine microzooplankton and freshwater rotifers, then marine and freshwater diatoms are grazed by marine and freshwater copepods. Similarly, marine and freshwater bacteria are consumed by marine microzooplankton and rotifers, themselves under the grazing pressure of marine and freshwater copepods. Exception is for large marine Phaeocystis colonies and freshwater filamentous cyanobacteria that are reported as unpalatable. Phaeocystis colonies escape grazing, but are submitted to colony disruption which releases nanoflagellates cells and organic matter in the water. To account for the osmotic stress caused by salinity changes, the mortality of PFTs is modulated by a function of salinity $(\mathrm{limS})$. This parameter is specific to marine and freshwater PFT (Table 2) and was derived from existing experiments testing the effect of salinity on Phaeocystis colonies (Peperzak, 2002) and stenohaline and marine euryhaline diatoms (Roubeix and Lancelot, 2008; Roubeix et al., 2008). Similarly to phytoplankton, zooplankton (e.g. Cervetto et al., 1999; Nielsen et al., 2003) and bacteria (e.g. Bouvier and del Giorgio, 2002; Schultz and Ducklow, 2000) are reported as sensible to osmotic chock. However, in the absence of observations to quantify the effect of osmotic stress on heterotrophic organisms, the relationships to salinity developed for euryhaline marine and freshwater diatoms were respectively applied to marine and freshwater zooplankton and bacteria.

The degradation of organic matter by planktonic bacteria is described considering three classes of biodegradability for both dissolved and particulate polymers distinguished on basis of their biodegradability (labile, semi-labile and refractory) and biogenic silica (BSi). These pools are each expressed in C (DC1, DC2, DC3, PC1, PC2, PC3), N (DN1, DN2, DN3, PN1, PN2, PN3) and P (DP1, DP2, DP3, PP1, PP2, PP3) (Table 1). The hydrolysis of these polymers produces dissolved monomers (BSC, BSN) that can be taken up by bacteria (Fig. 2). Inorganic nutrients include $\mathrm{NO}_{3}^{-}, \mathrm{NH}_{4}^{+}, \mathrm{Si}(\mathrm{OH})_{4}$ and $\mathrm{PO}_{4}^{3-}$, the latter being involved in adsorption and desorption on/from SPM. Hence inorganic $\mathrm{P}$ is described by two state variables: the total inorganic $\mathrm{P}$ (PIT) and $\mathrm{PO}_{4}^{3-}$. At each time step, the model considers that $\mathrm{PO}_{4}^{3-}$ is in rapid adsorption-desorption equilibrium with inorganic particulate phosphorus (PIP), according to an hyperbolic relationship proposed by Billen et al. (2007). Benthic organic matter degradation and nutrient recycling are calculated using the algorithms developed by Thouvenot et al. (2007).

\subsection{Model implementation}

Model simulations were performed for the year 2006. The hydrodynamic model is forced at Vlissingen with observed sea surface elevation extracted from the DONAR database maintained by the Rijkswaterstaat (Dutch Ministerie van Infrastructuur en Milieu) and made available through the WATERBASE online application (http://live.waterbase.nl). The concentration of the two sediments at the downstream boundary is relaxed towards constant values that are representative of the concentration of marine sediments (Villars and Vos, 1999). At the upstream boundaries (Ghent and lateral tributaries; Fig. 1), 10-day mean values for river discharges and SPM concentrations are imposed using the results of the Seneque-Riverstrahler model. The biogeochemical marine boundary conditions are provided by 3D-MIRO\&CO model simulations (Gypens et al., 2011) and correspond to daily values of the state variables extracted at Vlissingen in 2006. At the downstream boundary, the freshwater phytoplankton, zooplankton and bacteria are set to zero. At the upstream boundaries (Ghent and lateral tributaries; Fig. 1), marine phytoplankton, zooplankton and bacteria are set to zero and the model uses 10-day mean values for biogeochemical state variables extracted from the results of the Seneque-Riverstrahler model applied to the whole watershed of the Scheldt (Passy et al., 2013-this issue). In addition, the model takes into account the inputs from point and diffuse sources along the simulated Scheldt estuary. The point loads, i.e. urban and industrial effluents (SPM, nutrients, organic matters and bacteria) are estimated from (i) the effective volume delivered (depending on the effectiveness of the treatment plant), (ii) the type of treatment applied and (iii) their exact location in the Scheldt estuary. Diffuse sources (SPM, nutrients and organic matters) are calculated from rainfall and a constant average composition of nutrients (determined on the basis of empirical data or results of agronomic and hydrogeological models; Passy et al., 2013-this issue) allocated according to land use and lithological classes in the watershed.

The time evolution of the state variables is calculated by solving the different equations expressing mass conservation according to the Euler procedure. A time step of $15 \mathrm{~min}$ is used for the numerical integration. 
Marine

Freshwater

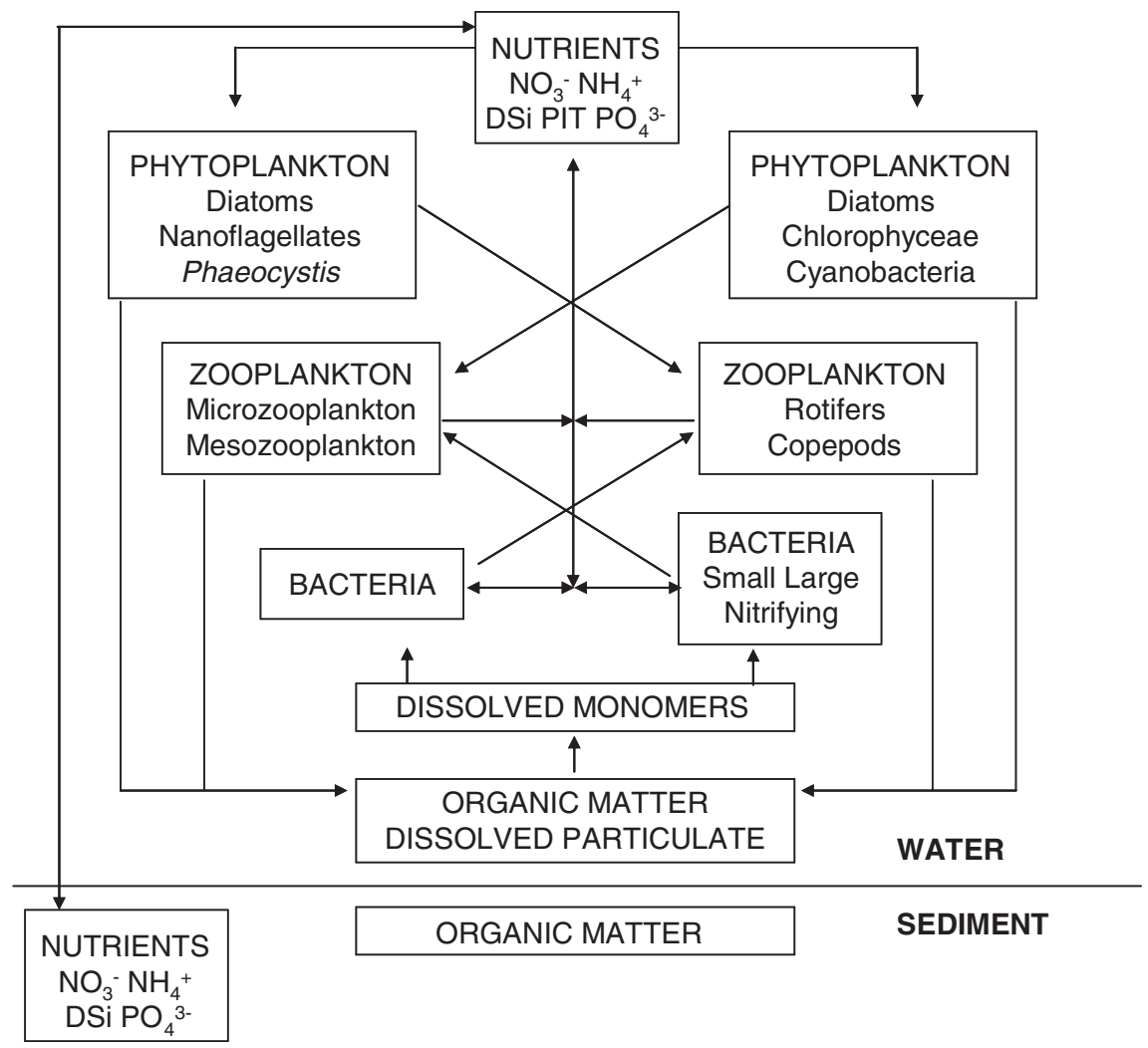

Fig. 2. Schematic representation of the structure of the RIVE-MIRO biological model.

Initial conditions imposed on the whole estuary are calculated as the average of the winter conditions simulated by the RIVE and MIRO models for the upstream and downstream boundary conditions. A spin-up of 30 days is considered before the actual simulation.

Model runs are performed using daily water surface temperature and surface incident light. The underwater light climate depends on the vertical light extinction coefficient $\left(\mathrm{ke}, \mathrm{m}^{-1}\right.$ ) which itself relies on light absorption by phytoplankton, detrital particles and coloured dissolved organic matter. This dependence has been formulated specifically for the Scheldt estuary based on existing measurements of ke $\left(\mathrm{m}^{-1}\right)$, chlorophyll a (Chl $a, \mu \mathrm{Chl.1} \mathrm{l}^{-1}$ ) and SPM (mg.l $\left.{ }^{-1}\right)$ as follows:

$\mathrm{ke}=0.042 * \mathrm{SPM}+0.02 * \mathrm{Chl} a+0.2$

\subsection{Validation data}

The physical, chemical and biological observations (SPM, salinity, temperature, $\mathrm{O}_{2}$, nutrients, Chl $a$, phytoplankton, organic carbon) available in the Scheldt estuary were downloaded from four national (RIKZ (http://www.waterbase.nl), BMDC (http://www.mumm.ac.be/ datacentre/) and regional (VMM (http://www.vmm.be/geoview/), OMES project (http://www.vliz.be/projects/omes/data.php) databases.

Table 2

Salinity function applied to planktonic organisms.

\begin{tabular}{ll}
\hline & Salinity function \\
\hline Phaeocystis colonies & $-0.0386 * \mathrm{SAL}+1.9643$ \\
Euryhaline marine diatoms & $-0.002 * \mathrm{SAL}$ SAL $+0.069 * \mathrm{SAL}+0.8938$ \\
Stenohaline freshwater diatoms & $0.2 * \mathrm{SAL}+1$ \\
Euryhaline freshwater diatoms & $0.0009^{*} \mathrm{SAL}$ SAL $-0.0243^{*} \mathrm{SAL}+1.1318$ \\
\hline
\end{tabular}

Freshwater diatom data were provided by Van Burm, Vyverman et al. (unpubl.; http://www.vliz.be/projects/omes/downloads.php).

\subsection{Statistical analysis}

In addition to the visual qualitative assessment of the model results, the coefficient of determination $\left(R^{2}\right)$ and the percent bias (Pbias) computed between model results and data were used to assess and rate the model performance. The statistics were estimated based on annual (Figs. 3-5; Table 3) and daily (Fig. 6, Table 4) values available at each validation stations along the Scheldt estuary. The coefficient of determination describes the degree of collinearity between simulated and measured data and expresses the proportion of the variability in the data set that can be explained by the model. Overall, $\mathrm{R}^{2}$ ranges from 0 to 1 (perfect fit) and values larger than 0.5 are considered acceptable (e.g. Moriasi et al., 2007). The percentage model bias (Pbias, the sum of model errors normalised by the data) measures the average tendency of the simulated values to under- (positive values) or over- (negative values) estimate the observations. The optimal value of Pbias is 0 , with low-magnitude values indicating accurate model simulation. Performance levels based on Pbias are rating excellent ( $\mid$ Pbias $\mid<10 \%)$, very good $(10$ $20 \%$ ), good (20-40\%) or poor (>40\%) (Allen et al., 2007; Maréchal, 2004). Pbias computed for $\mathrm{N}$ and $\mathrm{P}$ can however be judged as satisfactory if values are $\leq|70 \%|$ (Moriasi et al., 2007).

\section{Results}

The ability of the 1D-RIVE-MIRO biogeochemical model to reproduce physico-chemical and phytoplankton trends in the Scheldt estuary is evaluated by visual and statistical comparison of model simulations with available observations for the year 2006. Statistical 

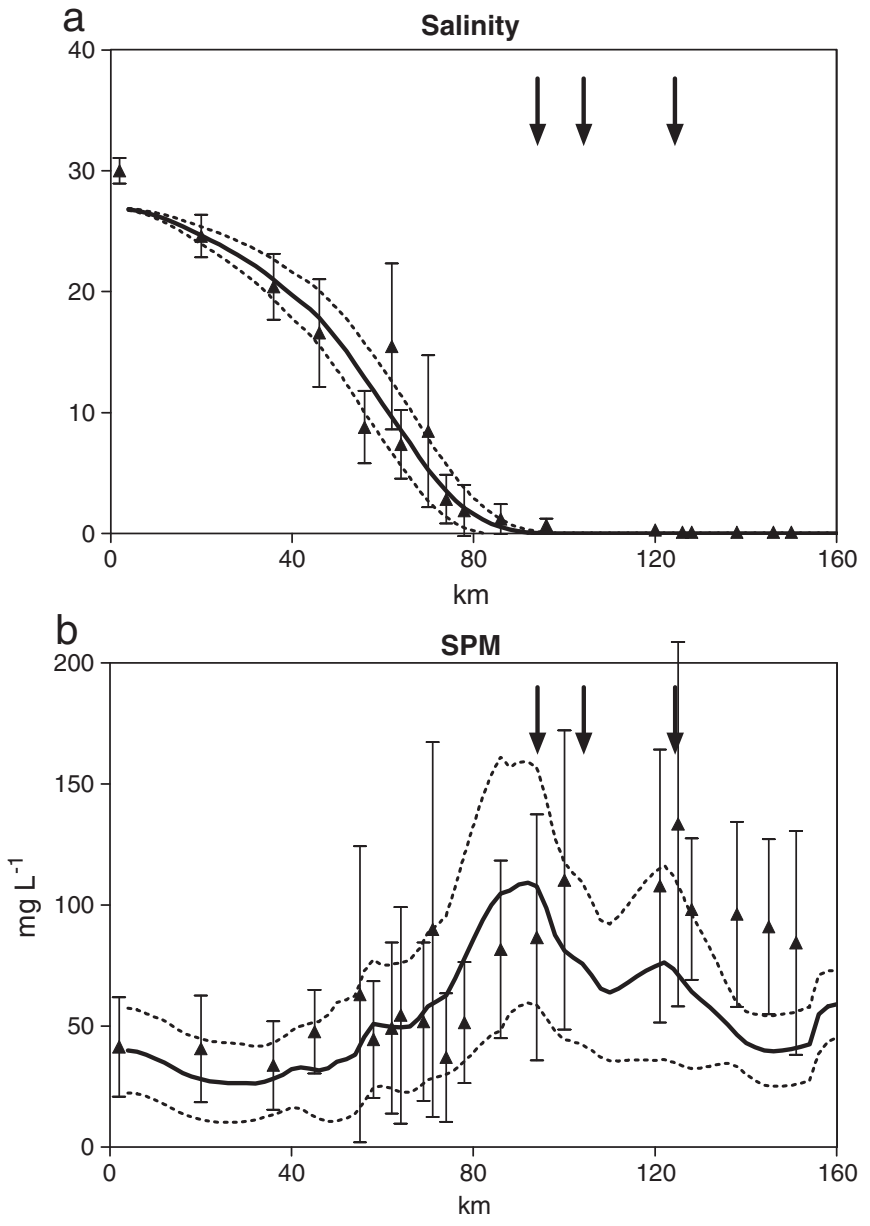

Fig. 3. Longitudinal evolution of RIVE-MIRO simulated (solid line) and measured (triangle) annual mean ( \pm standard deviation) of SAL (a) and SPM (b) along the Scheldt estuary for the year 2006. The arrows correspond to the localization of the input from lateral tributaries (respectively from the Dender, the Durme and the Rupel from upstream to downstream). Dashed line is the standard deviation of simulated results.

comparisons were performed by averaging model results and observations by geographical location and for the same time period, i.e. yearly (Table 3 ) or daily (Table 4).

\subsection{Annual estuarine profiles of biogeochemical variables}

Figs. 3 and 4 compare the modelled estuarine longitudinal profiles with available observations in 2006. Both observations and modelled data were annually averaged and their range of variability is shown by the standard deviation (SD). The coefficient of determination $\mathrm{R}^{2}$ (Table 3 ) rates the model performance with respect to the spatial variability of both physical and biogeochemical variables (Sal, SPM, DIN, $\mathrm{DSi}, \mathrm{PO}_{4}^{3-}, \mathrm{O}_{2}$ and $\mathrm{Chl}$ a). $\mathrm{R}^{2}$ is good (higher than 0.5 ) for salinity, DIN, $\mathrm{PO}_{4}^{3-}$, DSi and Chl $a$, near acceptable for $\mathrm{O}_{2}$ but low $(\sim 0.3)$ for SPM. The lower value obtained for SPM is mainly associated with the underestimation of the mean concentration in the upstream part of the model. Note also that the actual variability of SPM is very large because of the complex and highly non-linear deposition/resuspension dynamics. Overall the model is thus able to capture the observed upstream-downstream variability. The calculated bias is rated excellent for salinity, very good for $\mathrm{PO}_{4}^{3-}$, good for DSi, Chl $a$, SPM and $\mathrm{O}_{2}$. However, the Pbias values (higher than $|40 \%|$ ) obtained for DIN suggests that the simulated values are overestimated (Table 3; Fig. 4a). These values are however still acceptable considering the value of $\pm 70 \%$ proposed by Moriasi et al. (2007).
As expected, the simulated salinity shows an upstream-downstream decrease with values greater than 20 from the mouth to the $\mathrm{km} \mathrm{40-50} \mathrm{depending} \mathrm{on} \mathrm{the} \mathrm{period} \mathrm{of} \mathrm{the} \mathrm{year.} \mathrm{The} \mathrm{salinity} \mathrm{gradient,}$ between $\mathrm{km} 20$ and 80 is well described by the model (Fig. 3a). The standard deviation envelope captures the range of variability induced by spring-neap tidal cycle and the seasonal variation of the river discharge. The intrusion of marine waters is more important in summer due to the lower river discharge. The salinity approaches zero around $\mathrm{km} 75$ in winter and around $\mathrm{km} 90$ in summer. Upstream km 90, the impact of marine waters is negligible all around the year (Fig. 3a).

Despite the low $\mathrm{R}^{2}$ (Table 3 ), the annual mean longitudinal profile of SPM is also well captured by the model (Fig. 3b) and shows two maxima of turbidity ( $>150 \mathrm{mg} \mathrm{L}^{-1}$ ) between $\mathrm{km} 80$ and 120 . These coincide with the observed local maxima reported by Muylaert et al. (2000) at, respectively, the freshwater-seawater interface (zero salinity) and the freshwater tidal reaches. In both the model and the observations, a relatively large zone of increased turbidity appears around $\mathrm{km} \mathrm{90.} \mathrm{This} \mathrm{is}$ associated with a local maximum of the rate of dissipation of tidal energy by friction on the bottom (e.g. Arndt et al., 2007; Regnier et al., 1997). Annual mean SPM simulated in the upper part of the estuary are lower than the observations, although still in the data SD envelope and are higher than SPM values simulated in the marine part of the estuary (Fig. 3b).

As a general pattern, annual mean concentrations of inorganic nutrients (DIN $\left(\mathrm{NH}_{4}^{+}+\mathrm{NO}_{3}^{-}\right.$), DSi and $\mathrm{PO}_{4}^{3-}$; Fig. 4) decrease along the salinity gradient (Fig. 3a) due to the important dilution of the upstream input by seawater. The increased concentration simulated between $\mathrm{km} 110$ and 90 coincides with the tributary discharges (Fig. 1). At this location, the annual DIN (Fig. 4a) and DSi (Fig. 4b) concentration can reach respectively 700 and $160 \mathrm{mmol} / \mathrm{m}^{-3}$. The observed evolution of DIN (Fig. 4a) and DSi (Fig. 4b) in the salt gradient is well reproduced. This is not the case in the upstream estuary where the model overestimates the DIN annual concentration and underestimates the DSi levels, as also shown by the respective Pbias (Table 3). This discrepancy between model results and observations is partly explained by the upstream boundary conditions $(\mathrm{km} 160$ and tributaries) simulated by the Seneque-Riverstrahler model that propagates in the upstream part of the estuary. Annual mean simulated DSi still remain in data SD envelope along the estuary in agreement with 'good' computed Pbias (Table 3). As pointed by the statistical analysis, the magnitude and longitudinal pattern of annual $\mathrm{PO}_{4}^{3-}$ is well simulated along the estuary with, however, simulated concentrations being in the lower range of observation (Table 3, Fig. 4c). Comparison with SPM (Fig. 3b) suggests that the simulated decrease of $\mathrm{PO}_{4}^{3-}$ at $\mathrm{km} 80$ and 120 (Fig. 4c) are due to its absorption on SPM. The mean annual $\mathrm{O}_{2}$ concentration (Fig. 4d) simulated along the estuary is maintained around $300 \mu \mathrm{mol} \mathrm{L}-1$ except between $\mathrm{km} 80$ and 100 where the concentration decreases down to $150 \mu \mathrm{mol} \mathrm{L}^{-1}$ due to the important bacterial biomass and organic matter imported by the tributaries (mainly the Zenne) that increase the nitrification and respiration processes (not shown). In general, the simulated dissolved oxygen concentrations slightly overestimate the averaged observations (Table 3, Fig. 4d).

The Chl $a$ concentration is calculated from the total (freshwater and marine) phytoplankton biomass simulated by the model making use of a C:Chl $a$ ratio (25 mg:mg; Lancelot et al., 2005). Supported by observations, the model suggests the development of two phytoplankton blooms along the estuary, one very modest in the marine area, downstream the MTZ, and the other, more important, in the freshwater tidal section (Fig. 5a). The slight underestimation of $\mathrm{Chl}$ $a$ (Fig. 5a) in the freshwater estuary (between $\mathrm{km} 120$ and 80) could be explained by the use of an inappropriate C:Chl $a$ ratio for freshwater phytoplankton. Indeed, $\mathrm{C}: \mathrm{Chl} a$ ratio measured in the Scheldt estuary highly varies with values between 1 and 70 (Lionard et al., 2008b). Sensitivity tests suggest that the model-data fit can be improved by modifying the C:Chl $a$ ratio (not shown). In 
a
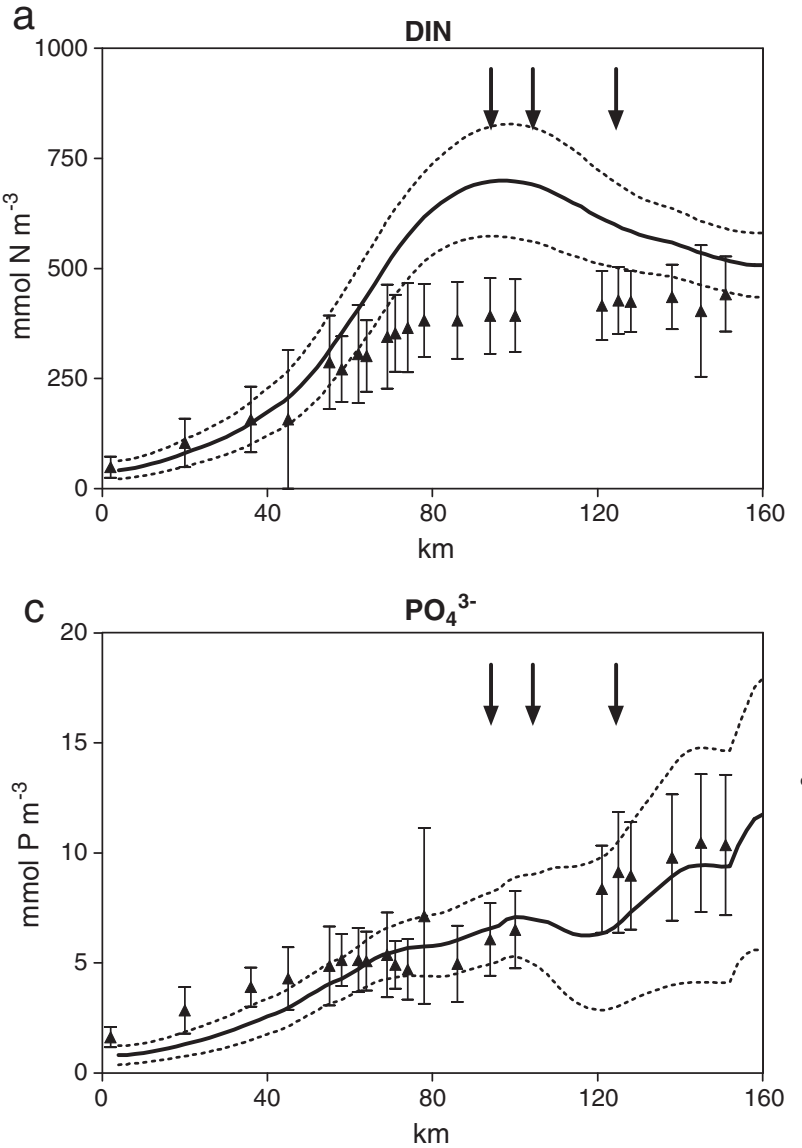

$\mathrm{b}$

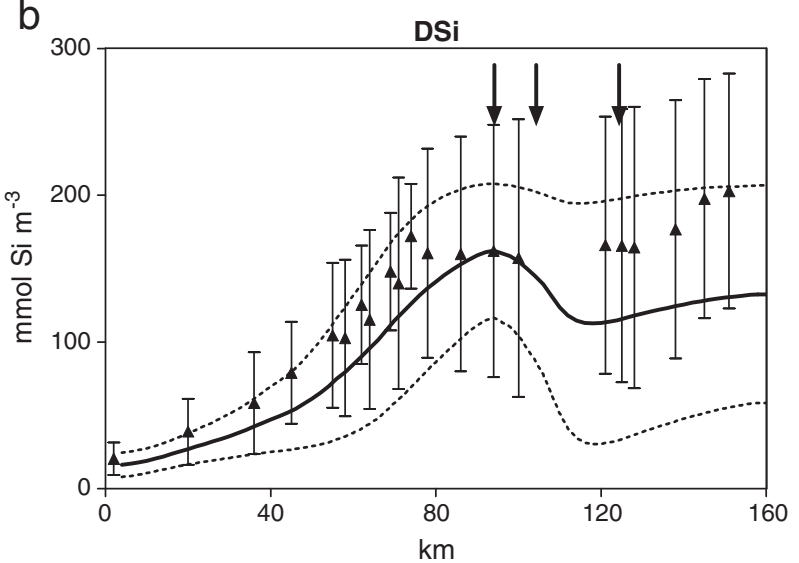

d

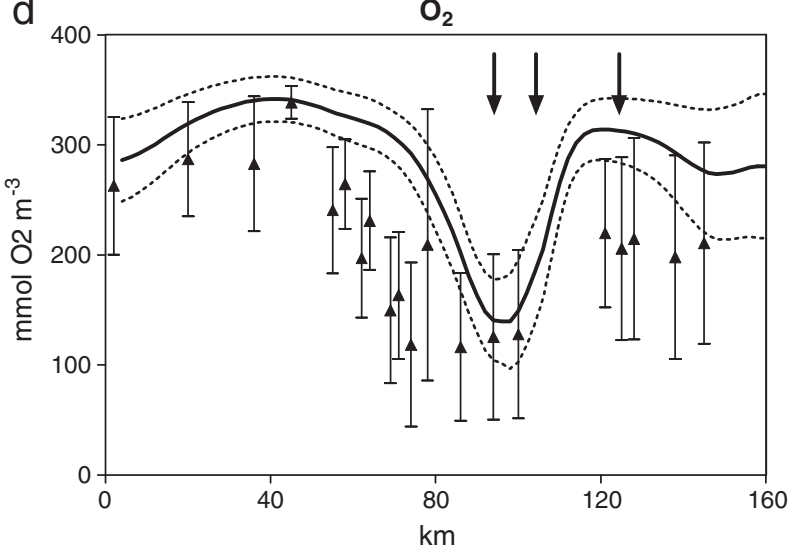

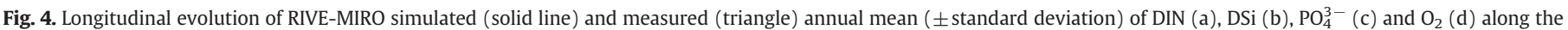

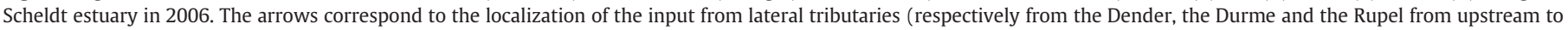
downstream). Dashed line is the standard deviation of simulated results.

parallel, the simulated freshwater diatom biomass that dominates the phytoplankton bloom in the upstream part of the estuary (Muylaert et al., 2000) agrees well with available observations in particular in the middle part of the estuary (Fig. 5b).

\subsection{Seasonal biogeochemical trends along the estuary}

The ability of the 1D-RIVE-MIRO model to capture the seasonal fluctuations can be appraised by comparing seasonal variations of simulated and observed inorganic nutrients ( $\mathrm{DIN}, \mathrm{PO}_{4}^{3-}$, DSi), oxygen concentration and Chl $a$ in different key zones of the Scheldt estuary (Fig. 6; Table 4). Overall, the seasonal signals are reasonably well represented in timing and amplitude for most of the selected variables and locations in the estuary (Fig. 6, Table 4). The coefficient of determination $\mathrm{R}^{2}$ computed between daily model results and available data at each validation station rates the model capacity to reproduce the seasonal variability of DSi, DIN and $\mathrm{PO}_{4}^{3-}$ as good (with value $>\sim 0.5$ ). $\mathrm{R}^{2}$ is lower ( 0.3) for $\mathrm{O}_{2}$ and Chl $a$ (Table 4 ). The performance level of Pbias value is from very good $\left(\mathrm{PO}_{4}^{3-}, \mathrm{DSi}\right)$ to good (DIN, $\mathrm{O}_{2}$ and $\mathrm{Chl} a$ ) (Table 4).

In agreement with observations, the simulated inorganic nutrient concentrations show a clear seasonal pattern characterised by higher values in winter, a progressive decrease during spring and summer as a response to phytoplankton growth, and an increase of nutrient concentrations in late summer and autumn (Fig. 6). The observed spring/ summer decrease of DIN is however not properly captured by the model between $\mathrm{km} 78$ and 120 where the simulated concentrations are overestimated. This results from the overestimation of DIN inputs by the Scheldt tributaries already pointed out in the analysis of the longitudinal profiles (Fig. 4a). For all sampled locations, the maximum DIN concentrations are simulated at the end of winter (heterotrophic regeneration and high river discharge) while minima are shown in late spring (phytoplankton uptake and low flow rate). In general the simulated DSi are in good agreement with observations but slightly underestimate observed summer values in the upstream part of the estuary (Fig. 4b). Despite this underestimation, the seasonal signal of DSi is correctly captured at every location along the estuary with both simulated and observed maxima in winter and minima in summer (Fig. 6). Yet, in the marine estuary, the simulated DSi seasonal variation is less marked than in the observations. The seasonal evolution of $\mathrm{PO}_{4}^{3-}$ is well reproduced in amplitude and timing for upstream stations and in the vicinity of the MTZs (Fig. 6). The high variability of modelled concentration results from absorption/desorption of PIT on particles and is related to the simulated SPM dynamics. The maximum concentration of PIT is simulated upstream ( $\mathrm{km} \mathrm{150)}$ in late summer and autumn (with concentrations above $15 \mu \mathrm{mol} \mathrm{L}{ }^{-1}$ ) when the river flow decreases. In the downstream part ( $\mathrm{km} 36$ and 20 ), the simulated seasonal signal is less pronounced than observed and the model fails to catch the amplitude of the observed summerfall increase. The seasonal variation of $\mathrm{O}_{2}$ is less well represented and model results tend to overestimate observations (Table 4; Fig. 6). The phytoplankton blooming period is reasonably well captured by the model at the different locations. The timing and amplitude of the Chl $a$ maximum are consistent with the observations, except in the maximum turbidity zone ( $\mathrm{km} 78$ ), where model results underestimate observations. 

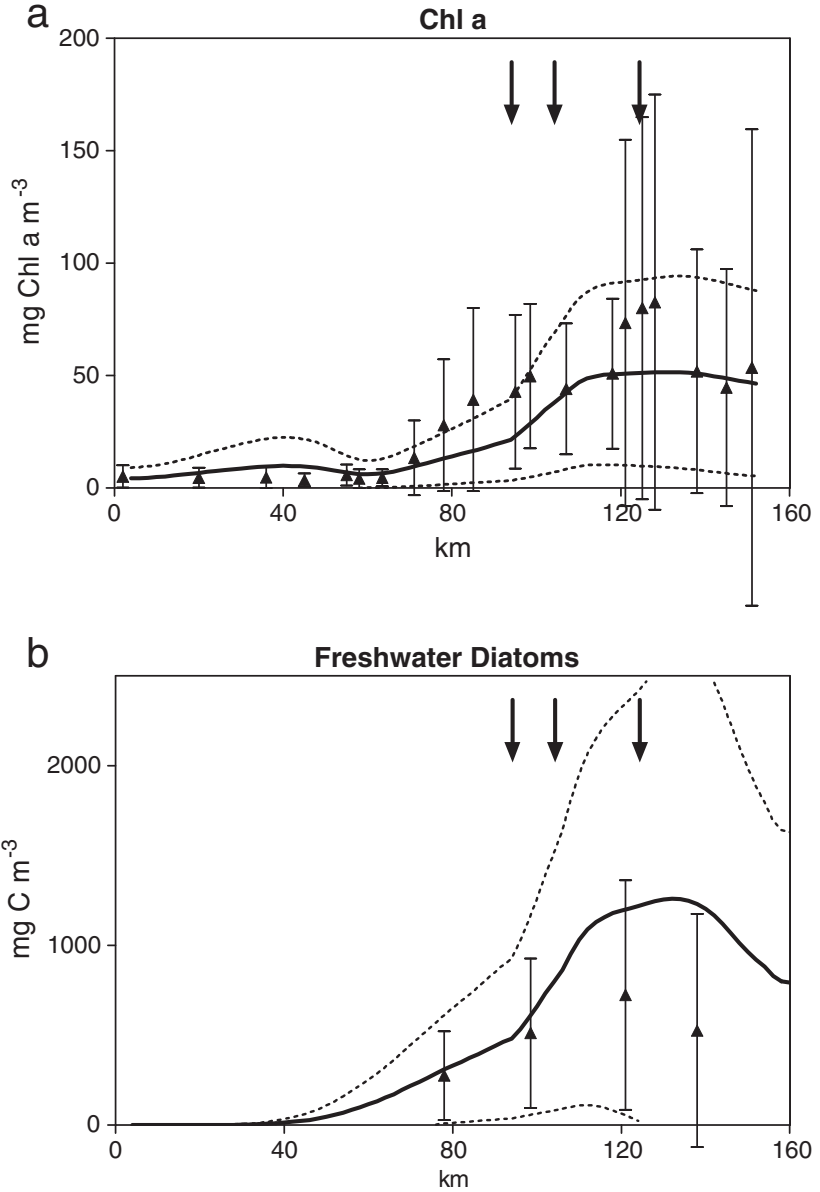

Fig. 5. Longitudinal evolution of RIVE-MIRO simulated (solid line) and measured (triangle) annual mean ( \pm standard deviation) of Chl $a$ (a) and freshwater diatoms (b) along the Scheldt estuary in 2006. The arrows correspond to the localization of the input from lateral tributaries (respectively from the Dender, the Durme and the Rupel from upstream to downstream). Dashed line is the standard deviation of simulated results.

The comparison of simulated freshwater diatom biomass with available data at 4 stations along the Scheldt estuary (Fig. 7) demonstrates the model capacity to reproduce the amplitude and the seasonal evolution of freshwater diatoms concentrations along the Scheldt estuary. In the upper part of the estuary, observed and simulated freshwater diatoms show a series of blooms between late spring and end-summer that reach biomass higher than $1000 \mathrm{mgC} \mathrm{m}^{-3}$ (Fig. 7a, b). The magnitude of freshwater diatoms bloom decreases downstream mainly during the spring period (Fig. 7c,d).

\subsection{Spatio-temporal evolution of PFTs}

Fig. 8 compares the geographical extent and the magnitude of freshwater and marine phytoplankton blooms. The spatial distribution of phytoplankton simulated in the Scheldt estuary suggests the occurrence of two distinct blooms, one in the freshwater and the other in the marine section of the estuary (Fig. 8). Such a distribution of riverine and coastal communities in the estuary has been reported by Muylaert et al. (2009). The absence of phytoplankton bloom between km 60 and 80 suggests that neither the freshwater nor the marine phytoplankton cross the MTZ at the saline transition. Overall the phytoplankton blooms between mid-April and late October (days 100 and 300) starting earlier in the marine section but extending longer in the upper estuary. The biomass reaches impressive levels upstream and corresponds with a series of blooms simulated between late spring and end-summer (Fig. 8). In agreement with observations (Lionard et al., 2005, 2008a; Muylaert et al., 2000), the upstream phytoplankton blooms are dominated by freshwater diatoms and Chlorophyceae with biomass as high as 4000 and $2500 \mathrm{mgC} \mathrm{m}^{-3}$, respectively (Fig. 8b,d), with the Chlorophyceae contributing significantly $(>50 \%)$ to phytoplankton in summer between $\mathrm{km} 140$ and 160. On an annual mean basis, other algal groups represent less than 10\% (Lionard et al., 2008b) and simulated cyanobacteria (not shown) represent a negligible biomass $\left(<2 \mathrm{mgC} \mathrm{m}^{-3}\right)$. As observed (Lionard et al., 2008a,b), freshwater phytoplankton is present from spring to early autumn. Overall the simulated freshwater diatoms penetrate further downstream than Chlorophyceae and reach their maximum in summer between $\mathrm{km} 140$ and 120 (Fig. 8b). Chlorophyceae show their maximum biomass at km 140 and generally disappear downstream km 100 (Fig. 8d). As a result of different light adaptation (or adaptation to turbulence), diatoms were found to be the dominant phytoplankton species in the freshwater tidal reaches of the Scheldt while Chlorophyceae were found to be more successful in the tributaries rivers, especially in summer (Lionard et al., 2005). Throughout the year, simulated and observed (Lionard et al., 2005) Chl $a$ and phytoplankton biomass declined in the brackish reaches. Nutrient limitation only impacts freshwater diatoms in late summer between $\mathrm{km} 150$ and 110 .

In the marine part of the estuary, the simulated phytoplankton bloom is maximum in summer and extends to $50 \mathrm{~km}$ upstream. It is characterised by the marine diatom-Phaeocystis-diatom succession (Fig. 8a,c), typical of coastal waters (Rousseau et al., 2002). Phaeocystis colonies dominate the marine phytoplankton biomass with maxima reaching $2000 \mathrm{mgC} \mathrm{m} \mathrm{m}^{-3}$ between $\mathrm{km} 20$ and 50 (Fig. 8c). The simulated marine diatoms biomass is very modest except in the first $30 \mathrm{~km}$ between late March and late April, with biomass up to $150 \mathrm{mgC} \mathrm{m}^{-3}$ (Fig. 8a). In the marine part, nutrients only limit diatoms growth and can partly explain their low biomass. The marine nanoflagellates (not shown) are present in small amounts with biomass always $<10 \mathrm{mgC} \mathrm{m}^{-3}$. The lack of blooming in spite of a supply of nanoflagellates cells after Phaeocystis colony disruption (Lancelot et al., 2005) is explained by the grazing pressure of marine microzooplankton (see below).

Fig. 9 shows the simulated spatio-temporal variations of freshwater and marine heterotrophic plankton. As expected from the spatio-temporal distribution of their prey, freshwater and marine microzooplankton and copepod distributions show distinct spatial distributions. The time slot and spatial occurrence of marine microzooplankton and copepods are between mid-April and late July and extends to the first $60 \mathrm{~km}$ (Fig. 9a,c) with a biomass of up to 100 and $30 \mathrm{mgC} \mathrm{m}^{-3}$ respectively, i.e. negligible compared to their prey. The success of microzooplankton can be related to the release of nanoflagellates in the ambient water after the disruption of ungrazed Phaeocystis colonies and the low significance of mesozooplankton that could control their development (Figs. 8c, 9a,c). Similarly, the biomass

Table 3

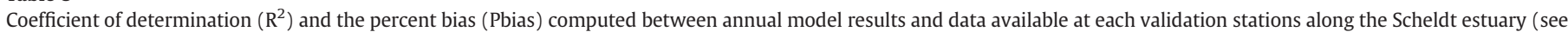
Figs. 3-5). All of the correlations are significant at the 95\% confidence level.

\begin{tabular}{|c|c|c|c|c|c|c|c|}
\hline & DIN & PO4 & DSi & $\mathrm{O}_{2}$ & Chl a & SPM & SAL \\
\hline $\mathrm{R}^{2}$ & $\begin{array}{l}0.88(\mathrm{~S}) \\
\mathrm{p}<0.0001\end{array}$ & $\begin{array}{l}0.83(\mathrm{~S}) \\
\mathrm{p}<0.0001\end{array}$ & $\begin{array}{l}0.83(\mathrm{~S}) \\
\mathrm{p}<0.0001\end{array}$ & $\begin{array}{l}0.47(\mathrm{~S}) \\
\mathrm{p}=0.0007\end{array}$ & $\begin{array}{l}0.83(\mathrm{~S}) \\
\mathrm{p}<0.0001\end{array}$ & $\begin{array}{l}0.33(\mathrm{~S}) \\
\mathrm{p}=0.0069\end{array}$ & $\begin{array}{l}0.94(\mathrm{~S}) \\
\mathrm{P}<0.0001\end{array}$ \\
\hline Pbias & -43 & 11.1 & 23 & -36.9 & 21.9 & 23.7 & 1.8 \\
\hline
\end{tabular}



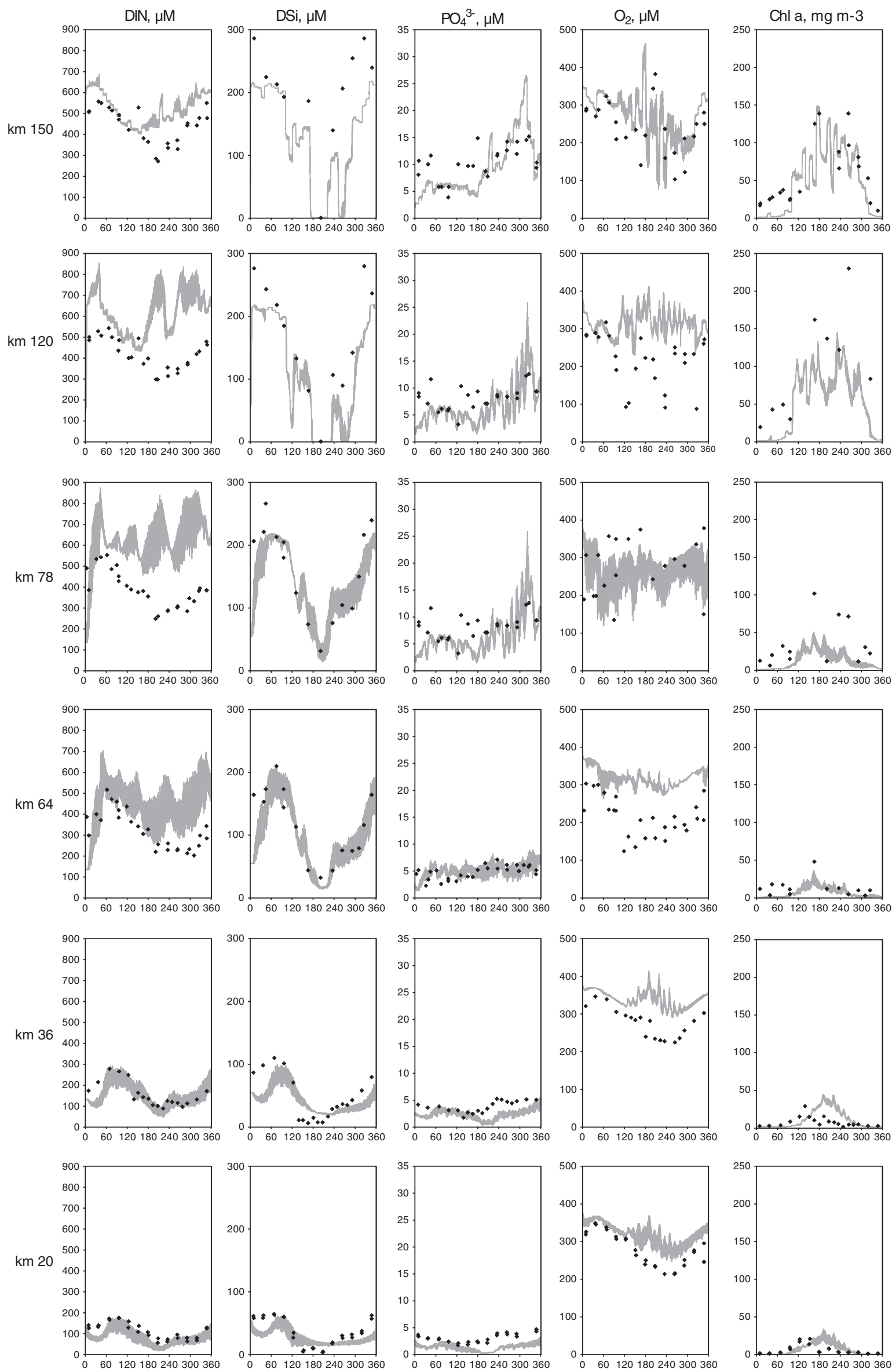

Fig. 6. Seasonal evolution of RIVE-MIRO simulated (solid line) and measured (dot) DIN, DSi, $\mathrm{PO}_{4}^{3-}, \mathrm{O}_{2}$ and Chl $a$ concentration at km 150, 120, 78, 64, 36 and 20 of the estuary in 2006 . 
Table 4

Coefficient of determination $\left(\mathrm{R}^{2}\right)$ and the percent bias (Pbias) computed between daily model results and data available at each validation stations along the Scheldt estuary (see Fig. 6). All of the correlations are significant at the 95\% confidence level.

\begin{tabular}{llllll}
\hline & $\mathrm{DIN}$ & $\mathrm{PO}_{4}$ & $\mathrm{DSi}$ & $\mathrm{O}_{2}$ & $\mathrm{Chl} \mathrm{a}$ \\
\hline $\mathrm{R}^{2}$ & $0.54(\mathrm{~S})$ & $0.47(\mathrm{~S})$ & $0.74(\mathrm{~S})$ & $0.33(\mathrm{~S})$ & $0.32(\mathrm{~S})$ \\
& $\mathrm{p}<0.0001$ & $\mathrm{p}<0.0001$ & $\mathrm{p}<0.0001$ & $\mathrm{p}<0.0001$ & $\mathrm{p}<0.0001$ \\
Pbias & -38.7 & 11.3 & 16.3 & -29 & 19 \\
\hline
\end{tabular}

of freshwater copepods and microzooplankton (Fig. 9b,d) are not significant, excepted between late June and early October, when microzooplankton biomass increases up to $400 \mathrm{mgC} \mathrm{m}^{-3}$ due to the presence of a large amount of Chlorophyceae (Figs. 8d, 9b).

Our model shows the presence of marine bacteria in the first $40 \mathrm{~km}$ between mid-February and mid-April with a maximum concentration of $60 \mathrm{mgC} \mathrm{m}^{-3}$ (Fig. 9e). They remain nevertheless present in lower amounts during the rest of the year with concentrations below $40 \mathrm{mgC} \mathrm{m}{ }^{-3}$. Contrasting with marine bacteria, whose development corresponds with the release of authochtonous organic matter, extremely high biomass of freshwater bacteria (>200 $\mathrm{mgC} \mathrm{m}^{-3}$; Fig. 9f) are shown in the upper Scheldt and at the confluence of the Scheldt with the tributaries due to the discharge of large quantities of both bacteria and organic matter.

\section{Discussion}

\subsection{Model assessment}

Model validation shows the model capacity to reproduce seasonal and longitudinal evolution of the physical and biogeochemical variable in the Scheldt estuary with however a significant overestimation of DIN concentration at the confluence with the lateral tributaries. This $\mathrm{N}$ overestimation mainly results from uncertainties on determining inputs from point sources, in particular, in the Dyle and the Nete rivers. The effect of DIN overestimation on estuarine phytoplankton dynamics was investigated by decreasing DIN river inputs by a factor 2 . Modifying $\mathrm{N}$ loads has no impact on freshwater phytoplankton but decreases maximum Phaeocystis biomass of about $200 \mathrm{mgC} \mathrm{m}^{-3}$ ( $10 \%$ of the reference simulation) around $\mathrm{km} 40$. In absence of important nutrient limitation of phytoplankton growth in the estuary, this discrepancy will only marginally affect the analysis of phytoplankton dynamics in the Scheldt. However, nutrient exports to the coastal zone are largely controlled by river inputs and annual flows of nutrients, $\mathrm{N}$ in particular, must be carefully considered and will be only discussed in a comparative and qualitative way.

Several physical-biogeochemical 1D (Cox et al., 2009; Hofmann et al., 2008; Regnier et al., 1997; Soetaert and Herman, 1995a; Vanderborght et al., 2002) or 2D (Arndt et al., 2007, 2009; Vanderborght et al., 2007) models were previously implemented in the Scheldt estuary to study $\mathrm{C}$, nutrients and/or $\mathrm{O}_{2}$ biogeochemical transformations and fluxes. In these estuarine models, phytoplankton process formulations are generally based on total primary production (generally associated to diatoms growth) without distinction between phytoplankton groups (e.g. Hofmann et al., 2008) or only simulate a limited period of time (e.g. summer time; Arndt et al., 2007; Vanderborght et al., 2007). These models are appropriate to reproduce the annual or decadal evolution of biogeochemical processes and concentration along the Scheldt estuary with sometimes a better result than those obtained with our complex model (for $\mathrm{N}$ and $\mathrm{O}_{2}$ in particular). In particular, Hofmann et al. (2008) present estuarine annual $\mathrm{C}$ and $\mathrm{N}$ budgets and fluxes and describe the spatial patterns of a

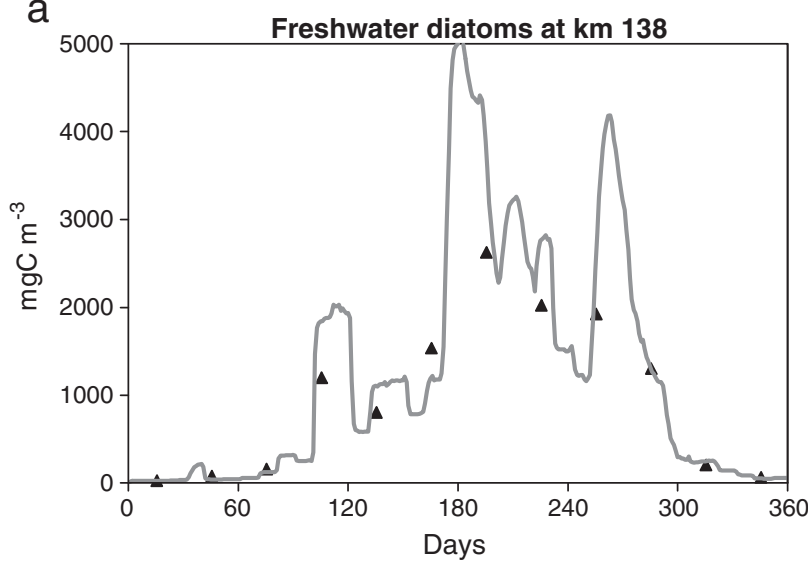

C

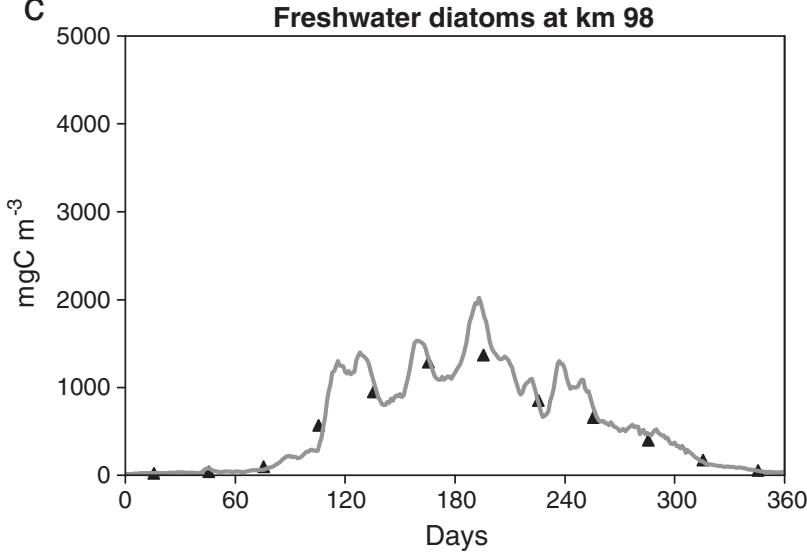

b
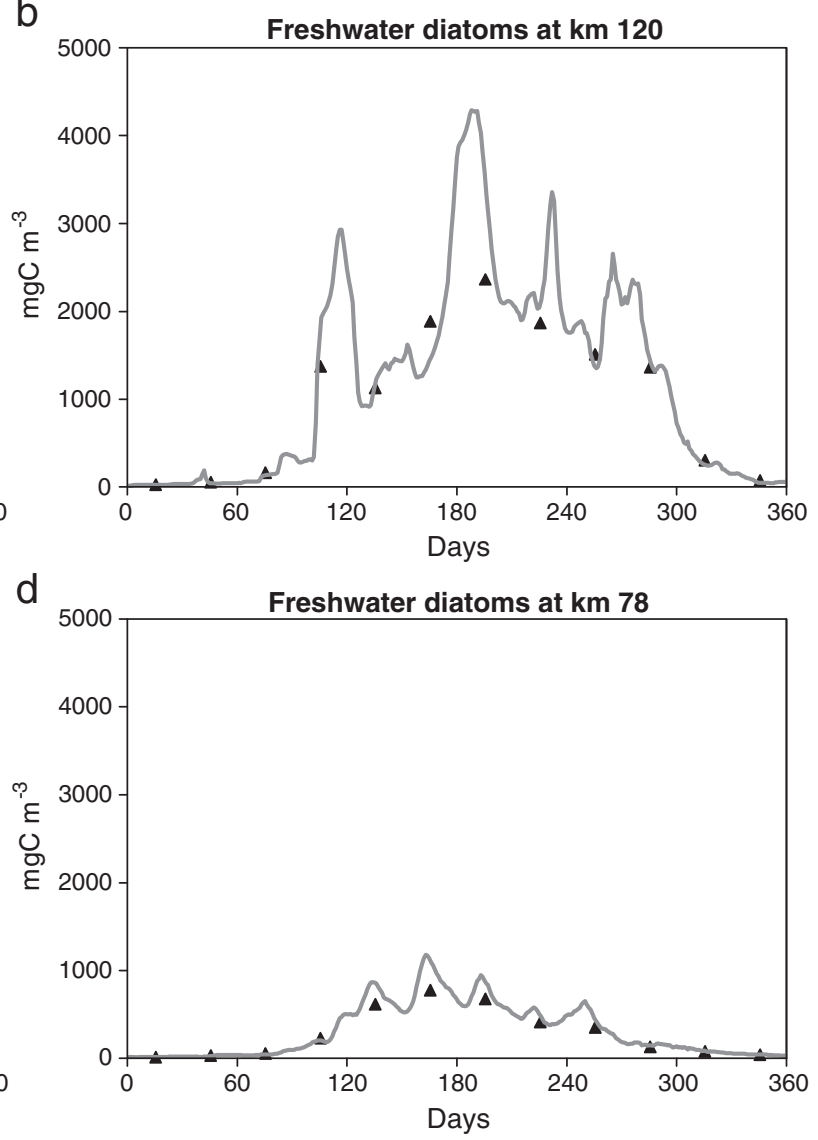

Fig. 7. Seasonal evolution of RIVE-MIRO simulated (solid line) and measured (dot) freshwater diatoms concentration at km $138,120,98$ and 78 of the estuary in 2006. 
a

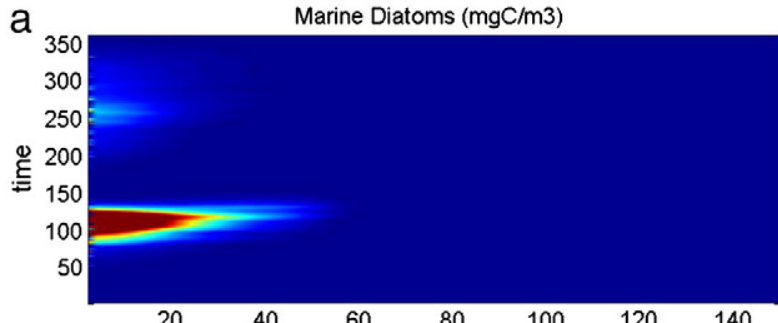

20

C

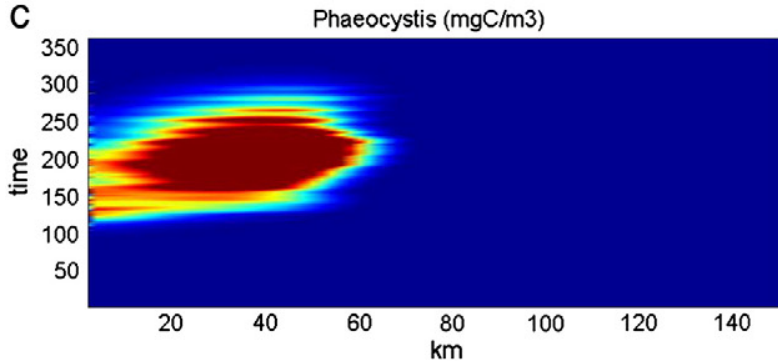

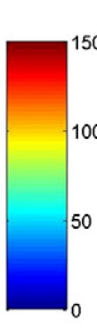

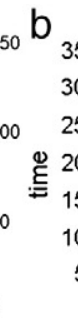

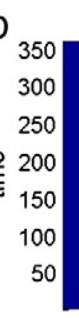

Freshwater Diatoms $(\mathrm{mgC} / \mathrm{m} 3)$

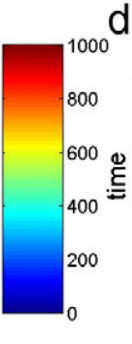

d

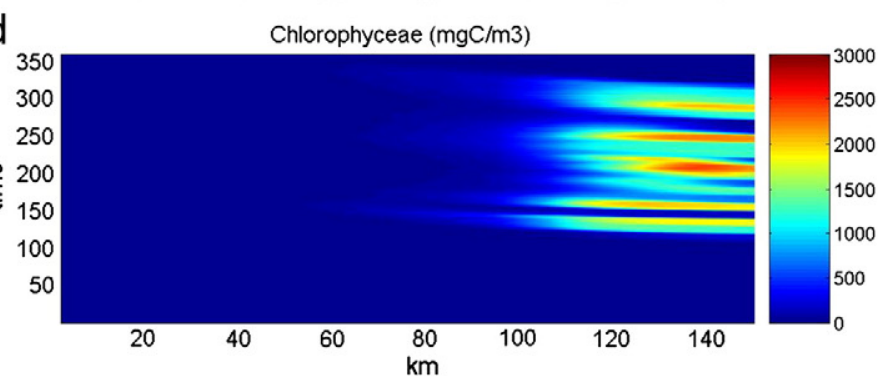

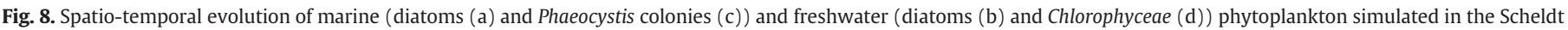
estuary by the 1D-RIVE-MIRO model in 2006.

nutrient concentrations and fluxes in the Scheldt estuary for average conditions representing the 2001-2004 period. Arndt et al. (2009) estimate seasonal $\mathrm{N}$ and $\mathrm{Si}$ transformations and fluxes along the entire continuum of the Scheldt estuary over a period of one year. However, none of these models can be used to understand the dynamics of phytoplankton in the estuary because they do not describe explicitly the processes associated with the mixing of the marine and freshwater communities as tempted in the here described RIVE-MIRO model.

In addition, most of the previous modelling studies were limited to the saline estuary (from Vlissingen to Rupelmonde) (Regnier and Steefel, 1999; Regnier et al., 1997; Soetaert and Herman, 1995a; Vanderborght et al., 2002) and ignored the role of the tidal river where nutrient transformation processes are particularly intense (Fig. 6). Yet the extension of the model domain to the tidal river was considered by Vanderborght et al. (2007) and Arndt et al. (2009). One step further, our application that couples an explicit description of the watershed with the estuarine model permits to estimate the impact on the Scheldt estuary of the modification of human activity on the watershed and the export to the coastal waters. The off-line coupling of a watershed, an estuarine and a coastal model avoids the need for providing boundary conditions at the boundaries of the different models.

\subsection{Control of phytoplankton succession in the estuary}

At the interface between freshwater and marine ecosystems, estuaries provide complex and fluctuating habitats for freshwater and marine phytoplankton where salinity gradient, light availability and water residence time control phytoplankton dynamics (Lancelot and Muylaert, 2012). In the Scheldt estuary, our model results suggest the development of distinct blooms in the freshwater and the marine sections of the estuary (Fig. 8). a
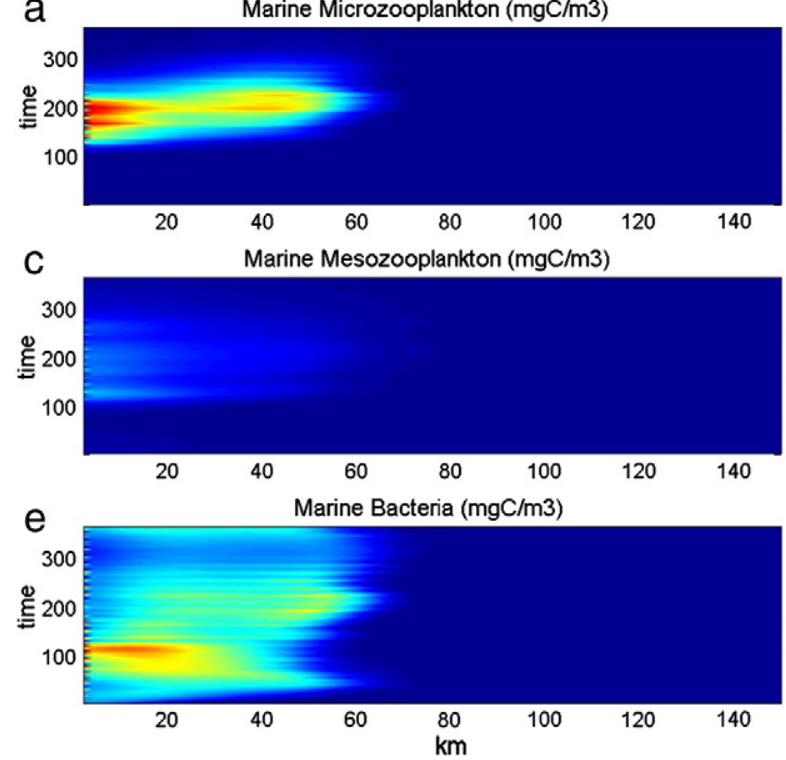

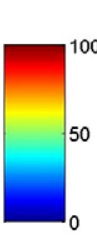

b
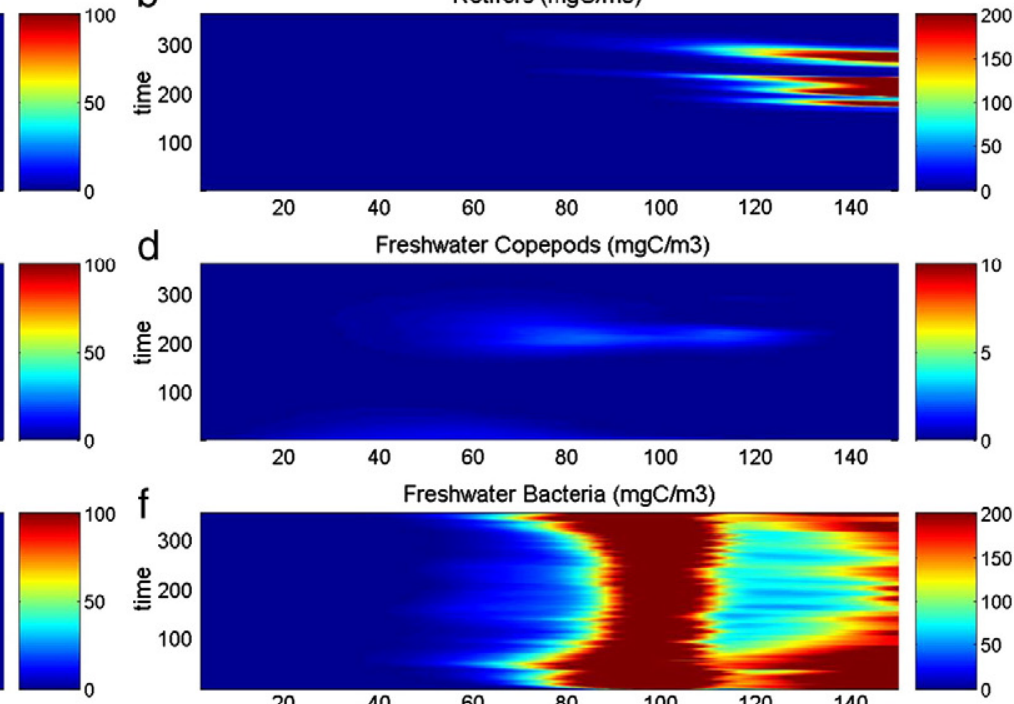

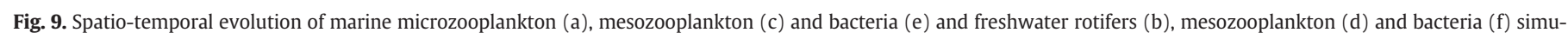
lated in the Scheldt estuary by the 1D-RIVE-MIRO model in 2006. 
a

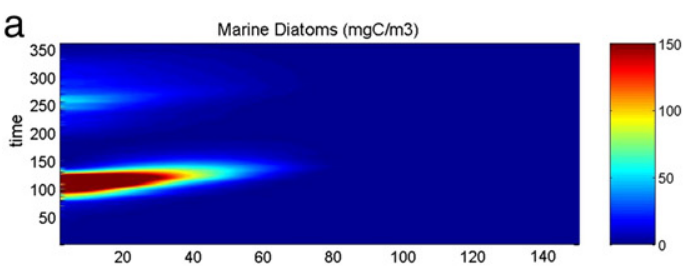

Phaeocystis (mgC/m3)

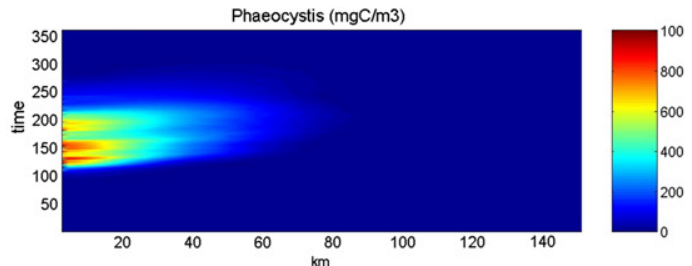

C
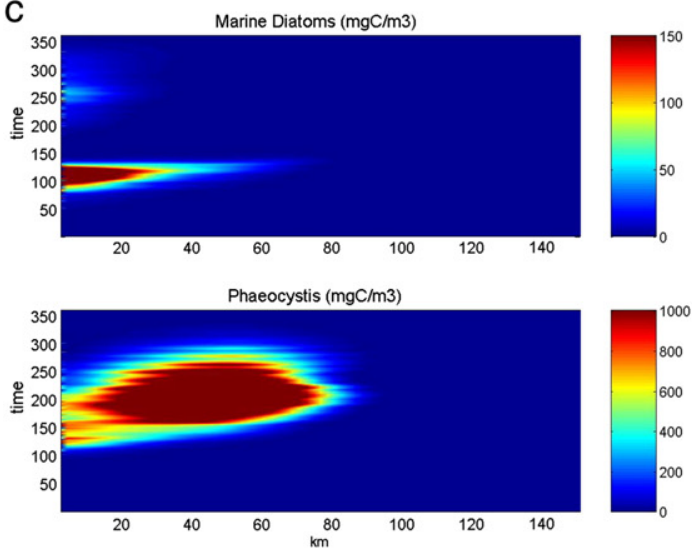

e

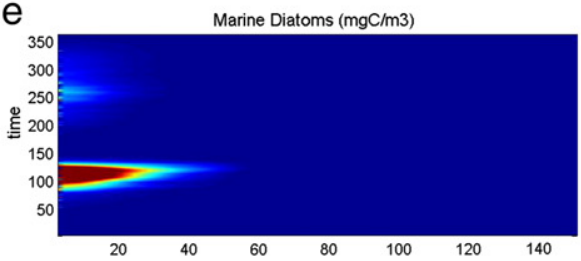

haeocystis (mgC/m3)

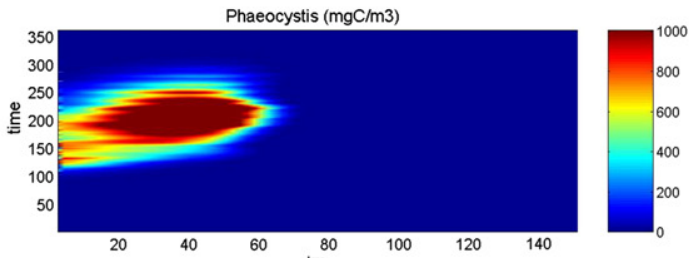

g

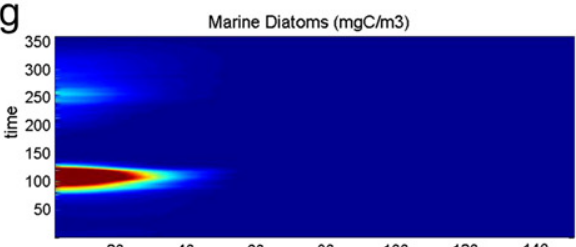

Phaeocystis (mgC/m3)

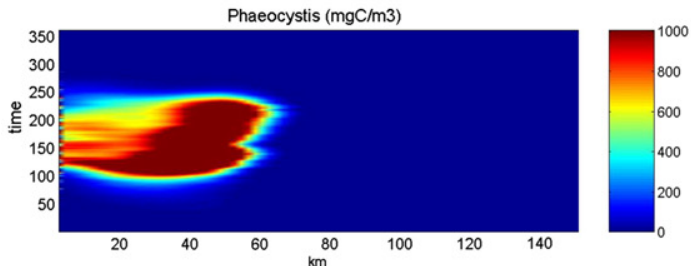

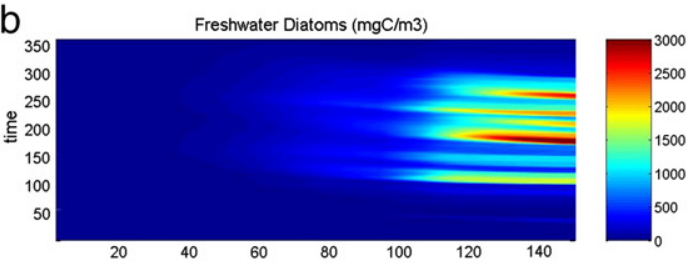

Chlorophyceae $(\mathrm{mgC} / \mathrm{m} 3)$
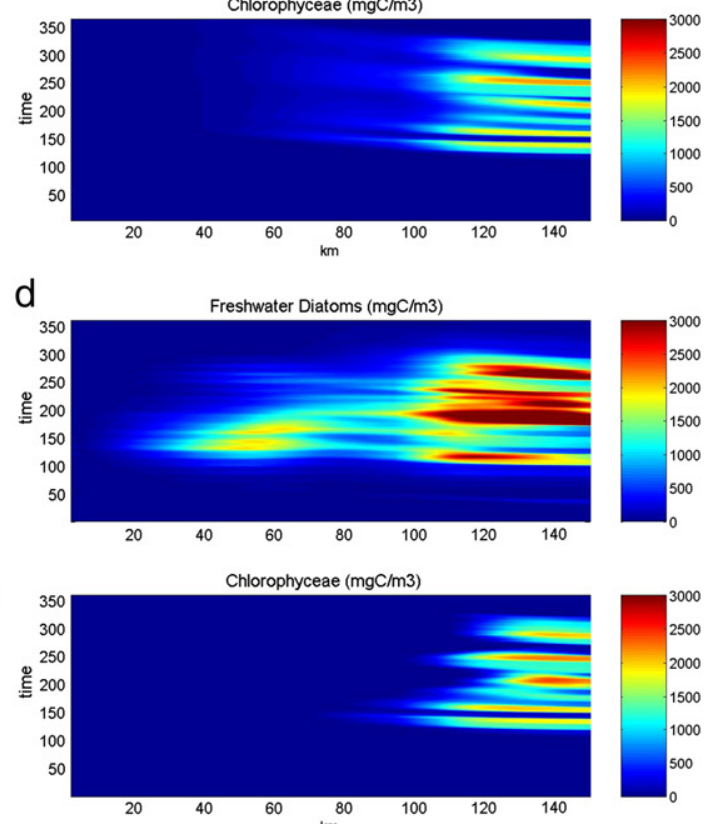

f
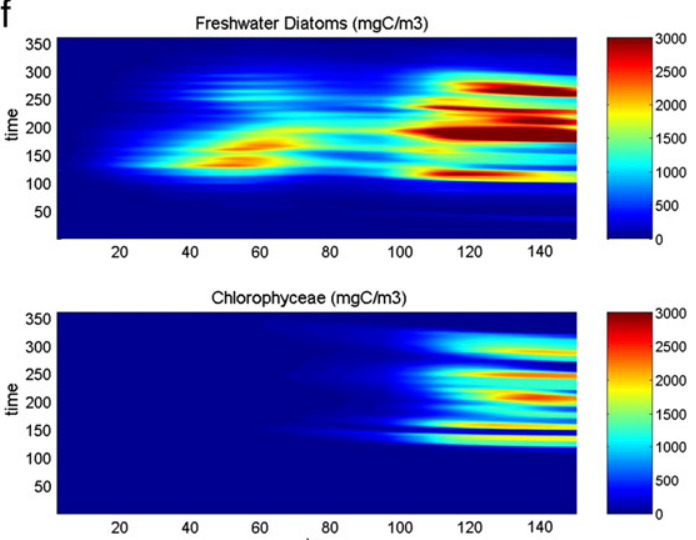

h
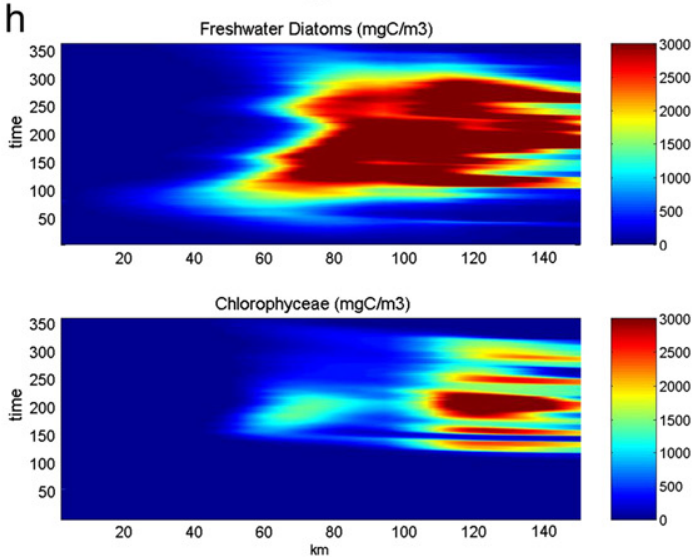

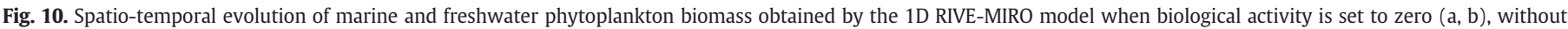

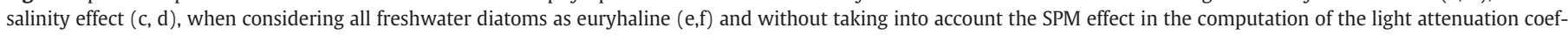
ficient $(\mathrm{g}, \mathrm{h})$ 
Different sensitivity tests were performed to understand the mechanisms controlling the simulated phytoplankton succession in the estuary (Figs. 10,11). The relative contribution of the physical transport and of the biological processes on the simulated phytoplankton patterns is estimated by comparing the reference spatio-temporal distribution of freshwater and marine phytoplankton biomass (Fig. 8) with those obtained when setting all biological activities to zero (Fig. 10a,b). Model results are analysed based on the difference between the two simulations (sensitivity test - reference; Fig. 11a,b) with negative value indicative of bloom development in the reference simulation and positive one of a better survival in the estuary when biological processes are neglected. When only the physical transport is taken into account, the simulated freshwater and marine phytoplankton biomasses decrease from the upstream and downstream boundaries respectively (Fig. 10a,b). In the upper estuary, Chlorophyceae and freshwater diatoms remain relatively constant between the $\mathrm{km} 160$ and 120 with maximal biomass around $2500 \mathrm{mgC} \mathrm{m}^{-3}$ (Fig. 10b) and decrease after due to the important dilution by tributaries and marine waters. The negative values obtained in the upstream part of the estuary (Fig. 11b) indicate the growth capacity of freshwater diatoms and to a less extent Chlorophyceae. The higher penetration of transported freshwater phytoplankton in the estuary (positive difference in Fig. 11a,b) up to $\mathrm{km} 60$ is explained by the absence of salinity-related mortality in the simulation with no biological activity. In absence of biological processes, Phaeocystis and marine diatom are transported more upwards (up to km 70; Fig. 11a). Interestingly the difference pattern shown in Fig. 11a indicates that Phaeocystis colonies grow in the lower estuary mainly in summer. On the contrary the positive difference obtained for marine diatoms imported in the downstream part of the estuary (Fig. 11a) suggests a dominance of loss over growth processes (grazing, lysis and/or sedimentation) in the reference simulation.

The extent to which the salinity-related mortality was responsible of the simulated bimodal distribution of freshwater and marine phytoplankton was investigated by neglecting this effect on PFTs (phytoplankton, zooplankton and bacteria) and by comparing the corresponding spatiotemporal distributions of freshwater and marine phytoplankton to the reference (Figs. 10c,d, 11c,d). In absence of salinity effect, freshwater diatoms allow to cross the MTZ and bloom between $\mathrm{km} 40$ and 80 in the salt gradient, reaching biomass of about $1300 \mathrm{mgC} \mathrm{m} \mathrm{m}^{-3}$ (Figs. 10d, 11d). Similarly, marine phytoplankton biomass increases in the salt gradient, especially Phaeocystis whose bloom extends up to $\mathrm{km} 80$ (Figs. 10c, 11c). Yet, the impact on phytoplankton biomass is limited because removing the effect of salinity on zooplankton increases their grazing pressure on phytoplankton. This is particularly marked in the freshwater estuary where the microzooplankton pressure on Chlorophyceae is stronger when the salinity-induced mortality is not considered (Fig. 11d).

In the reference simulation, freshwater diatoms are considered as composed at $90 \%$ by stenohaline species while $10 \%$ are euryhaline. The consequence of this choice on phytoplankton distribution was explored by running the model with varying freshwater assemblage (composed at $30 \%, 50 \%, 70 \%$ and $100 \%$ of euryhaline species). The presence (or absence) of euryhaline species has a strong impact on the distribution and magnitude of both freshwater and marine phytoplankton (Figs. 10e,f, 11e,f). Overall, increasing the percentage of euryhaline species by $>50 \%$ moves freshwater diatom growth downstream in the estuary, up to $\mathrm{km} 30$ where it competes with marine phytoplankton (not shown). As expected, results obtained when considering $100 \%$ of euryhaline species show a similar propagation of freshwater diatoms in the salinity gradient than that obtained in absence of salinity stress, with however a larger effect (Fig. 11d,f). Considering $100 \%$ of euryhaline freshwater species also impacts marine species (mainly Phaeocystis, Fig. 11e) by decreasing their penetration and growth in the estuary due to higher limitation of nutrient ( $\mathrm{P}$ mainly) and light (by increasing the shelf-shading related to freshwater diatom biomass).
The role of the SPM dynamics in controlling light availability and hence phytoplankton growth in the estuary was investigated with the 1D-RIVE-MIRO model after neglecting the effect of SPM in the parameterisation of the vertical light attenuation coefficient ke (Eq. (4)). In the reference simulation, the annual mean ke is higher than $2 \mathrm{~m}^{-1}$ (euphotic depth $=2.3 \mathrm{~m}$ ) all along the estuary with values up to 8 to $10 \mathrm{~m}^{-1}$ (euphotic depth $<1 \mathrm{~m}$ ) near the MTZs (not shown). By neglecting the impact of SPM, ke significantly decreases with annual mean values between 1 and $1.5 \mathrm{~m}^{-1}$ in the upper estuary and lower than $1 \mathrm{~m}^{-1}$ in the downstream estuary. The results obtained with the modified parameterization show a general increase of phyplankton biomass in the whole estuary throughout the year (Fig. 10g, h). Comparing this with the reference simulation shows an important increase of both freshwater diatoms and Chlorophyceae that can now cross the MTZ and develop up to $\mathrm{km} 50$ due to a better underwater climate (Figs. 10g,h, 11g,h). Maximal freshwater diatom biomass is still simulated around the $\mathrm{km} 120$ but increases by nearly a factor 2 with respect to the reference (i.e., $7000 \mathrm{mgC} \mathrm{m}^{-3}$; Fig. 10h). Chlorophyceae also increase and are now characterised by two maxima (of respectively 4800 and $1500 \mathrm{mgC} \mathrm{m}{ }^{-3}$ ) located near the $\mathrm{km} 130$ and 70 (Fig. 10h). The decrease of light limitation permits cyanobacteria to reach the downstream part of the estuary in summer (not shown). Due to increased competition for nutrient with freshwater phytoplankton, the impact of light availability is less important on the spatial extension of marine phytoplankton (Fig. $11 \mathrm{~g}$ ) but Phaeocystis biomass even increases to $3000 \mathrm{mgC} \mathrm{m}^{-3}$ near the $\mathrm{km} 40$ (Figs. $10 \mathrm{~g} ; 11 \mathrm{~g}$ ). The decrease of summer Phaeocystis biomass results from the competition with freshwater phytoplankton.

Additional simulations were performed to estimate the sensitivity of phytoplankton distributions to grazing pressure. Removing the latter has little impact on phytoplankton dynamics in the upstream part of the estuary but modifies the marine phytoplankton dominance with an increase of nanoflagellates and diatoms and a decrease of Phaeocystis biomass (not shown). Removing the effect of salinity on zooplankton increases the grazing pressure and decreases Chlorophyceae biomass in the upstream part of the estuary (not shown).

Altogether these sensitivity tests suggest that freshwater diatoms and Phaeocystis develop in the estuary while Chlorophyceae and marine diatoms are mainly transported from the river and marine boundaries respectively. Grazing pressure is negligible and can not explain the bulk phytoplankton distribution although it is partly responsible for the relative importance of diatom $v s$ non diatom patterns. In the absence of salinity-induced mortality, freshwater diatoms would cross the MTZ and grow in the downstream part of the estuary where they could compete for nutrients with marine phytoplankton. Similarly, the presence or absence of euryhaline freshwater species has a significant impact on the distribution and magnitude of freshwater and marine species. When accounting for more than 50\% of the total freshwater diatom biomass, euryhaline species bloom further downstream the MTZ and prevent the penetration and growth of marine species in the estuary. More than salinity or phytoplankton composition at the boundaries, light availability - strongly dependent on SPM concentration -, appears as the main factor controlling the phytoplankton distribution in the Scheldt estuary in 2006 and explain the sharp decrease of freshwater phytoplankton simulated between the $\mathrm{km} 100$ and 70.

\subsection{Estuarine biological control of nutrient export to the coastal zone}

A budget based on the 1D-RIVE-MIRO daily simulations of nutrient fluxes estimates to $1.84 \mathrm{Gmol} \mathrm{N}, 0.063 \mathrm{Gmol} \mathrm{P}$ and $0.47 \mathrm{Gmol} \mathrm{Si}$ the annual export of nutrients to the coastal zone in 2006 (Table 5). Nitrogen export is similar to that estimated by Hofmann et al. (2008) for the period 2001-2004 (2.2 $\mathrm{Gmol} \mathrm{N} \mathrm{y}^{-1}$ ). The comparison between simulated annual loads and those based on available discharge and nutrient concentrations (RIKZ) show an good correspondence for N $(2.08 \mathrm{Gmol} \mathrm{N}$ 

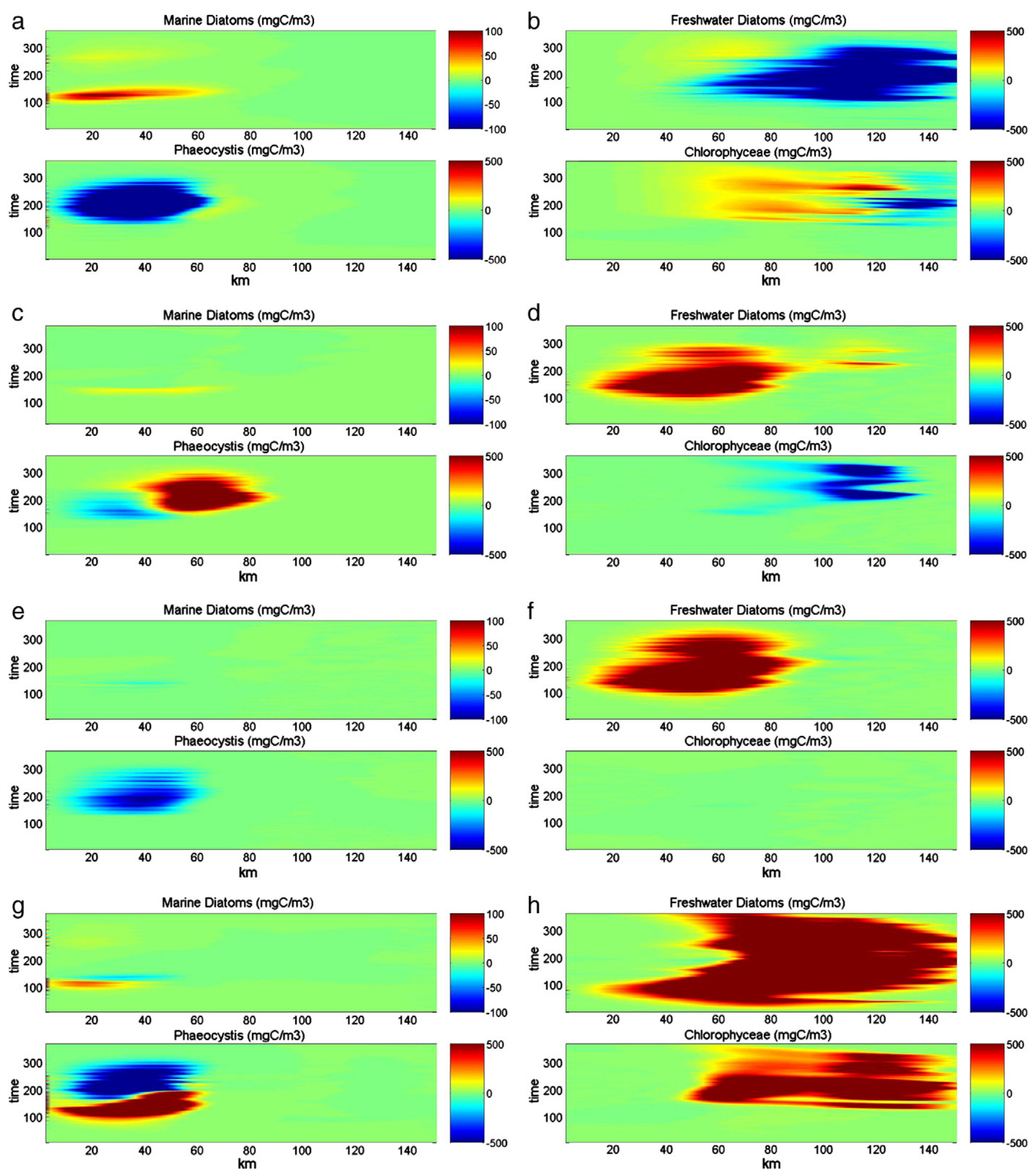

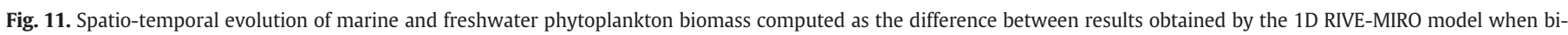

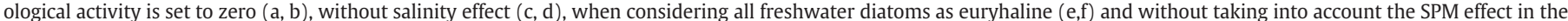
computation of the light attenuation coefficient (g,h) and the reference simulation.

$\left.\mathrm{y}^{-1}\right), \mathrm{P}\left(0.05 \mathrm{Gmol} \mathrm{P}^{-1}\right)$ and Si (0.045 Gmol Si $\mathrm{y}^{-1}$ ) (Lancelot and Gypens, submitted for publication - this issue). Biological activities transform nutrients during the estuarine transfer and modify the proportion of inorganic and organic forms ( $\mathrm{N}, \mathrm{P}$ and $\mathrm{Si}$ ) exported to the coastal zone compared to the river inputs to the favour of the inorganic ones (Table 5). Interestingly, as shown by Arndt et al. (2011), part of the biogenic $\mathrm{Si}(\mathrm{BSi})$ mineralised in the estuary is from marine origin and corresponds to the mineralisation of marine diatom frustules that 
Table 5

$\mathrm{P}, \mathrm{N}$ and $\mathrm{Si}$ export to the coastal zone (in $\mathrm{Gmol} / \mathrm{y}$ ) simulated in the reference simulation and sensitivity tests compared to the input to the estuary. Sensitivity tests include simulations where all biological activities are set to zero (NOBIO), the effect of SPM in the parameterisation of the vertical light attenuation coefficient ke is neglected (ke-SPM) and phytoplankton growth is prevented (NOPHY). Negative values correspond to an input from the coastal zone.

\begin{tabular}{llllll}
\hline & INPUT & \multicolumn{3}{l}{ OUTPUT } & \\
\cline { 3 - 6 } & & REF & NOBIO & ke-SPM & NOPHY \\
\hline PIT & 0.039 & 0.044 & 0.033 & 0.015 & 0.035 \\
DOP & 0.017 & 0.006 & 0.011 & 0.012 & 0.002 \\
POP & 0.018 & 0.013 & 0.016 & 0.022 & 0.007 \\
$\mathrm{NO}_{3}^{-}$ & 0.91 & 1.38 & 0.85 & 0.82 & 1.44 \\
$\mathrm{NH}_{4}^{+}$ & 0.80 & 0.07 & 0.62 & -0.02 & -0.06 \\
$\mathrm{DON}$ & 0.26 & 0.01 & 0.17 & 0.15 & -0.04 \\
$\mathrm{PON}$ & 0.26 & 0.38 & 0.23 & 0.67 & 0.12 \\
DSi & 0.61 & 0.53 & 0.47 & 0.22 & 0.59 \\
BSi & 0.07 & -0.06 & 0.06 & 0.26 & -0.20 \\
\hline
\end{tabular}

have penetrated the estuary ( $-0.06 \mathrm{Gmol} \mathrm{Si} / \mathrm{y}$, Table 2). In agreement with Hofmann et al. (2008), our results show that nitrification remains the main process governing the $\mathrm{N}$ cycle in the Scheldt estuary and the relative proportion of $\mathrm{NO}_{3}^{-}$and $\mathrm{NH}_{4}^{+}$with a net production of $\mathrm{NO}_{3}^{-}$ (Table 5 ). About $4 \%$ of the total $\mathrm{N}$ inputs are denitrified in the estuary and similar amount of $\mathrm{N}$ are retained in the sediment.

Eliminating biological activity in the estuary (NOBIO simulation; Table 5) allows estimating the importance of physical processes (transport of dissolved and particulate matter, adsorption/desorption and sedimentation/resuspension, dilution) controlling the export of nutrients to the coastal zone. Comparing this budget with the reference demonstrates the minor role played by the biological activity on the magnitude of the exported nutrients and its major influence on their chemical forms. The increased relative contribution of inorganic $v s$ organic nutrients (Table 5) suggests the dominance of bacterial organic matter mineralisation and nitrification over phytoplankton uptake in the Scheldt estuary (Table 5). This is confirmed by analysing the nutrients budget obtained when phytoplankton growth is prevented (simulation NOPHY; Table 5) and biological transformations due to heterotroph processes only. In addition, this simulation suggests that the export of inorganic nutrients available for coastal phytoplankton yet relies on the ability of phytoplankton to grow (or not) in the estuary (Table 5). This is demonstrated by calculating the nutrient budget obtained when maximizing the phytoplankton growth in the estuary (no effect of SPM in ke formulation; simulation ke-SPM; Table 5).

\subsection{Prospective scenario}

Prospective scenarios were performed to investigate the impact of human activity in the Scheldt watershed on the estuarine phytoplankton dynamics and on the nutrient export to the coastal zone. In particular, the operation of the wastewater treatment plant in 'Brussels North' in 2007 could have an important impact on the amount and speciation of nutrients discharged into the Zenne and then after in the Scheldt estuary. Two nutrient reduction scenarios have been considered: (i) the upgrading of wastewater treatment plants (WWTP) and (ii) the conversion of conventional agriculture to organic farming. The upgrading of WWTP is based on the implementation of the European Directive on Urban Waste Water Treatment (91/271/EEC) and implies the upgrading of the main plants (treatment capacity $>2000$ inhabitant equivalent (IE)) to a more advanced treatment of $\mathrm{N}$ and $\mathrm{P}$ corresponding to a reduction of respectively 70\% and 90\% (Thieu et al., 2010). For the organic farming scenario, the total agricultural area (grassland, arable land and heterogeneous agricultural areas) is assumed to adopt new farming practices that lead to limit the average subroot $\mathrm{NO}_{3}^{-}$concentration (Thieu et al., 2011).

Both the conversion to organic farming and the upgrading of WWTP decrease the nutrient inputs to the estuary by the main and lateral tributaries (Fig. 12). Interestingly the WWTP upgrading has a larger effect on nutrient delivered by the lateral tributaries (positive effect of the Brussels WWTP) while organic farming is more effective in the upper basin (Fig. 12). The impact of organic farming is limited to DIN with no effect on P and Si (Fig. 12b,c). Both organic farming and WWTP scenarios decrease the N inputs while only the WWTP scenario affects $P$ loads (Fig. 12a,b). The WWTP scenario decreases DIN especially in the freshwater estuary (Fig. 12a) but $\mathrm{PO}_{4}^{3-}$ (Fig. 12b) all along the estuary. The simulated decrease of phytoplankton in both the upper and marine
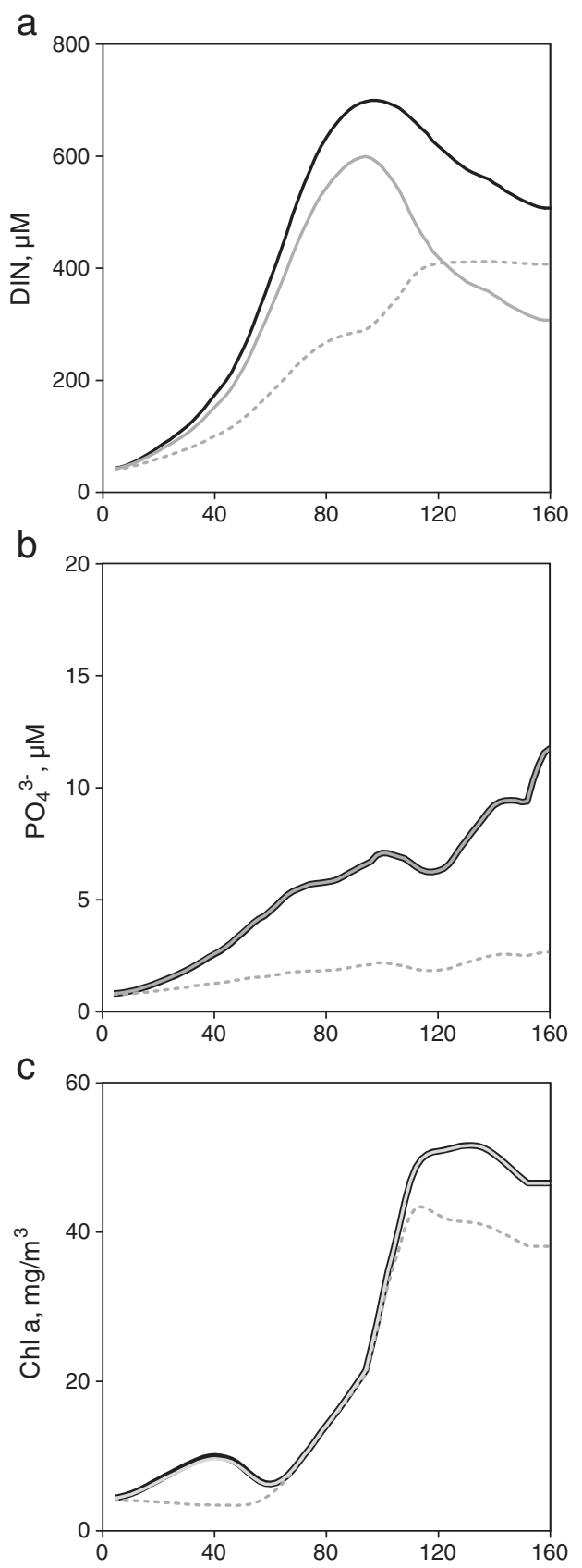

Fig. 12. Annual mean evolution of $\mathrm{DIN}(\mathrm{a}), \mathrm{PO}_{4}^{3-}$ (b) and Chl a (c) concentration computed for the reference simulation (black line), when running the 'WWTP' (grey dashed line) and 'organic farming' (grey line) scenario. 
Table 6

N, P and Si export to the coastal zone (in Gmol/y) computed for the reference simulation, the WWTP scenario and the organic farming scenario.

\begin{tabular}{llll}
\hline & Reference & WWTP & Organic Farming \\
\hline PIT & 0.044 & 0.024 & 0.040 \\
DOP & 0.006 & 0.004 & 0.005 \\
POP & 0.013 & 0.008 & 0.013 \\
$\mathrm{NO}_{3}^{-}$ & 1.38 & 0.71 & 1.13 \\
$\mathrm{NH}_{4}^{+}$ & 0.07 & 0.10 & 0.06 \\
$\mathrm{DON}$ & 0.01 & -0.02 & 0.01 \\
$\mathrm{PON}$ & 0.38 & 0.21 & 0.37 \\
$\mathrm{DSi}$ & 0.53 & 0.53 & 0.53 \\
$\mathrm{BSi}$ & -0.06 & -0.05 & -0.06 \\
\hline
\end{tabular}

estuary (Fig. 12c) mainly responds to a P growth limitation rather than N. An examination of PFT distribution shows that nutrient limitation affects Chlorophyceae between $\mathrm{km} 90$ and 150 and both marine diatoms and, mainly, Phaeocystis biomass in the downstream part of the estuary (not shown). The beneficial effect of DIN reduction, visible upstream after implementation of the organic farming scenario (Fig. 12a) is counteracted in the mid-estuary by point source DIN discharged by lateral tributaries. In consequence, the DIN longitudinal profile exhibits a maximum near $\mathrm{km} 90$ with no effect on the simulated Chl $a$ (Fig. 12c) and phytoplankton succession.

In term of export to the coastal zone, the WWTP upgrading scenario more than the agricultural scenario will drastically reduce $\mathrm{N}$ (as $\mathrm{NO}_{3}^{-}$) and $\mathrm{P}$ (as PIT) delivery to the coastal sea. In absence of decrease of $\mathrm{Si}$ export, the reduction of $\mathrm{N}$ and $\mathrm{P}$ fluxes and the improvement of N:P ratio compared to Si will favour diatoms compared to Chlorophyceae (not shown). Also modified is the inorganic to organic ratio of nutrient export with a decrease of the availability of inorganic nutrient for coastal phytoplankton (Table 6).

\section{Conclusion}

The coupled river-estuarine-marine model developed in this study is shown efficient to assess the present-day ecological status of the estuary and to test the effect of nutrient reduction options (upgrading of waste water upgrading, change in agricultural practices) on the nutrient processing in the estuary and, ultimately, on the export to the coastal zone. The model results demonstrate the importance of both salinity and light availability, driven by the SPM dynamics, to explain the bimodal freshwater and marine phytoplankton distribution, separated by the maximum turbidity zone near salinity zero. From an ecological perspective, the impact of salinity on phytoplankton mortality and/or the presence of euryhaline species in the phytoplankton assemblage are important and determine the magnitude and location of phytoplankton blooms in the estuary. Regarding the nutrient fluxes exported to the coastal zone, the effect of salinity on the plankton communities has little effect and is hidden by light limitation of growth. Overall, biological activity in the Scheldt estuary has little impact on the magnitude of total nutrients exported to the sea in 2006 but well on their quality. Through autotrophic and heterotrophic processes, biological activity modifies the relative importance of organic and inorganic forms of nutrients exported to the sea and their rate of transfer through the estuary. Intense (modest) phytoplankton growth in the estuary will favour the export of organic (inorganic) forms of nutrient. This has implication for coastal phytoplankton especially species strictly autotrophs. Nutrient reduction measures applied to the Scheldt basin are expected to modify the speciation but also the magnitude of nutrient exports to the coastal zone.

\section{Acknowledgment}

The present work is a contribution to the TIMOTHY (P6/13) and AMORE III Belgian Federal Projects funded respectively by the
Interuniversity Attraction Poles Programme and by the Science for Sustainable Development -'Belgian State - Belgian Science Policy BELSPO' and the AWARE project funded by respectively the 7th Framework Programs of the European Commission. The present work benefited from data obtained from the Onderzoek Milieueffecten Sigmaplan, Multidisciplinaire studie rond het estuariene milieu van de Zeeschelde OMES project. We are grateful to W. Vyverman (Protistology and Aquatic Ecology, Ugent, Belgium) and P. Meire (Universiteit Antwerpen, Belgium) for giving access to the relevant OMES data. We acknowledge two anonymous reviewers for constructive comments on a previous version of the manuscript.

\section{Appendix A. Supplementary data}

Supplementary data to this article can be found online at http:// dx.doi.org/10.1016/j.jmarsys.2012.10.006.

\section{References}

Allen, J.I., Holt, J.T., Blackford, J., Proctor, R., 2007. Error quantification of a highresolution coupled hydrodynamic-ecosystem coastal-ocean model: Part 2. Chlorophyll-a, nutrients and SPM. J. Mar. Syst. 68 (3-4), 381-404.

Appeltans, W., Hannouti, A., Van Damme, S., Soetaert, K., Vanthomme, R., Tackx, M. 2003. Zooplankton in the Schelde estuary (Belgium, The Netherlands). The distribution of Eurytemora affinis: effect of oxygen? J. Plankton Res. 25, 1441-1445.

Arndt, S., Vanderborght, J.-P., Regnier, P., 2007. Diatom growth response to physical forcing in a macrotidal estuary: coupling hydrodynamics, sediment transport, and biogeochemistry. J. Geophys. Res. 112, C05045. http://dx.doi.org/10.1029/ 2006JC003581.

Arndt, S., Regnier, P., Vanderborght, J.-P., 2009. Seasonally-resolved nutrient export fluxes and filtering capacities in a macrotidal estuary. J. Mar. Syst. 78, 42-58.

Arndt, S., Lacroix, G., Gypens, N., Regnier, P., Lancelot, C., 2011. Nutrient dynamics and phytoplankton development along an estuary-coastal zone continuum: a mode study. J. Mar. Syst. 84, 49-66.

Attrill, M.J., Rundle, S.D., 2002. Ecotone or ecocline: ecological boundaries in estuaries. Estuarine Coastal Shelf Sci. 55, 929-936.

Billen, G., Garnier, J., Rousseau, V., 2005. Nutrient fluxes and water quality in the drainage network of the Scheldt basin over the last 50 years. Hydrobiologia 540, 47-67.

Billen, G., Garnier, J., Nemery, J., Sebilo, M., Sferratore, A., Benoit, P., Barles, S., Benoit, M., 2007. A long term view of nutrient transfers through the Seine river continuum. Sci. Total. Environ. 375, 80-97.

Bouvier, T., del Giorgio, P.A., 2002. Compositional changes in free-living bacterial communities along the salinity gradient in two temperate estuaries. Limnol. Oceanogr. 47, 453-470.

Cervetto, G., Gaudy, R., Pagano, M., 1999. Influence of salinity on the distribution of Acartia tonsa (Copepoda, Calanoida). J. Exp. Mar. Biol. Ecol. 239, 33-45.

Cox, T.J.S., Maris, T., Soetaert, K., Conley, D.J., Van Damme, S., Meire, P., Middelburg, J.J. Vos, M., Struyf, E., 2009. A macro-tidal freshwater ecosystem recovering from hypereutrophication: the Schelde case study. Biogeosciences 6, 2935-2948.

Cugier, P., Billen, G., Guillaud, J.-F., Garnier, J., Ménesguen, A., 2005. Modelling the eutrophication of the Seine Bight (France) under historical, present and future riverine nutrient loading. J. Hydrol. 304 (1-4), 381-396.

Delhez, E.J.M., Wolk, F., 2012. Diagnosis of the transport of adsorbed material in the Scheldt estuary : a proof of concept. (http://dx.doi.org/10.1016/j.jmarsys.2012.01. 007).

Garnier, J., Billen, G., Hannon, E., Fonbonne, S., Videnina, Y., Soulie, M., 2002. Modeling transfer and retention of nutrients in the drainage network of the Danube river. Estuarine Coastal Shelf Sci. 54, 285-308.

Gazeau, F., Gattuso, J.P., Middelburg, J.J., Brion, N., Schiettecatte, L.S., Frankignoulle, M., Borges, A.V., 2005. Planktonic and whole system metabolism in a nutrient-rich estuary (the Scheldt estuary). Estuaries 28, 868-883.

Gypens, N., Lacroix, G., Lancelot, C., Borges, A.V., 2011. Seasonal and inter-annual variability of air-sea $\mathrm{CO}_{2}$ fluxes and seawater carbonate chemistry in the Southern North Sea. Prog. Oceanogr. 88, 59-77.

Hirsch, C., 1990. Computational methods for inviscid and viscous flows. Numerical Computation of Internal and External Flows, vol. 2. John Wiley \& Sons, New York (1990).

Hofmann, A.F., Soetaert, K., Middelburg, J.J., 2008. Present nitrogen and carbon dynamics in the Scheldt estuary using a novel 1-D model. Biogeosciences 5 (4), 981-1006.

Kromkamp, J.C., Peene, J., 2005. Changes in phytoplankton biomass and primary production between 1991 and 2001 in The Westerschelde Estuary (Belgium/The Netherlands). Hydrobiologia 540, 117-126.

Kromkamp, J.C., Van Engeland, T., 2010. Changes in phytoplankton biomass in the Western Scheldt Estuary during the period 1978-2006. Estuaries Coasts 33, $270-285$.

Lacroix, G., Ruddick, K., Park, Y., Gypens, N., Lancelot, C., 2007. Validation of the 3D biogeochemical model MIRO\&CO with field nutrient and phytoplankton data and MERIS-derived surface chlorophyll a images. J. Mar. Syst. 64 (1-4), 66-88.

Laforce, E., Wens, F., Roovers, P., 1977. Mathematisch model van het tijgebied der Schelde. Waterbouwkundig Laboratorium, Borgerhout, Belgium. 42 pp. 
Lancelot, C., Gypens, N., submitted for publication - this issue. How significant are present-day Phaeocystis colony blooms in the present-day Southern North Sea compared to a pseudo-pristine situation: a model study. J. Mar. Syst.

Lancelot, C., Muylaert, K., 2012. Trends in Estuarine Phytoplankton Ecology. In Treatise on Coastal and Estuarine Science. Biogeochemistry 8.

Lancelot, C., Veth, C., Mathot, S., 1991. Modelling ice edge phytoplankton bloom in the Scotia-Weddell Sea sector of the Southern Ocean during spring 1988. J. Mar. Syst. 2, 333-346.

Lancelot, C., Spitz, Y., Gypens, N., Ruddick, K., Becquevort, S., Rousseau, V., Lacroix, G., Billen, G., 2005. Modelling diatom and Phaeocystis blooms and nutrient cycles in the Southern Bight of the North Sea: the MIRO model. Mar. Ecol. Prog. Ser. 289, 63-78.

Lancelot, C., Gypens, N., Billen, G., Garnier, J., Roubeix, V., 2007. Testing an integrated river-ocean mathematical tool for linking marine eutrophication to land use: the Phaeocystis-dominated Belgian coastal zone (Southern North Sea) over the past 50 years. J. Mar. Syst. 64, 216-228.

LeVeque, R.J., 1992. Numerical Methods for Conservation Laws. Lecture in Mathematics. Birkhauser Verlag. 214 pp.

Lionard, M., Muylaert, K., Van Gansbeke, D., Vyverman, W., 2005. Influence of changes in salinity and light intensity on growth of phytoplankton communities from the Schelde river and estuary (Belgium/The Netherlands). Hydrobiologia 540, 105-115. http://dx.doi.org/10.1007/s10750-004-7123-x.

Lionard, M., Muylaert, K., Hanoutti, A., Maris, T., Tackxe, M., Vyverman, W., 2008a. Inter-annual variability in phytoplankton summer blooms in the freshwater tida reaches of the Schelde estuary (Belgium). Estuarine Coastal Shelf Sci. 79 (2008), 694-700.

Lionard, M., Muylaert, K., Tackx, M., Vyverman, W., 2008b. Evaluation of the performance of HPLC-CHEMTAX analysis for determining phytoplankton biomass and composition in a turbid estuary (Schelde, Belgium). Estuarine Coastal Shelf Sci. 76, 809-817. http://dx.doi.org/10.1016/j.ecss.2007.08.003.

Maréchal, D., 2004. A soil-based approach to rainfall-runoff modelling in ungauged catchments for England and Wales. PhD Thesis, Cranfield University, $157 \mathrm{pp}$.

Meire, P., Ysebaert, T., Van Damme, S., Van den Bergh, E., Maris, T., Struyf, E., 2005. The Scheldt estuary: a description of a changing ecosystem. Hydrobiologia 540, 1-11.

Mialet, B., Gouzou, J., Azémar, F., Maris, T., Sossou, C., Toumi, N., Van Damme, S., Meire P., Tackx, M., 2011. Response of zooplankton to improving water quality in the Scheldt estuary (Belgium). Estuarine Coastal Shelf Sci. 93, 47-57.

Moriasi, D.N., Arnold, J.G., Van Liew, M.W., Binger, R.L., Harmel, R.D., Veith, T., 2007 Model evaluation guidelines for systematic quantification of accuracy in watershed simulations. Trans. ASABE 50 (3), 885-900.

Muylaert, K., Sabbe, K., Vyverman, W., 2000. Spatial and temporal dynamics of phytoplankton communities in a freshwater tidal estuary (Schelde, Belgium). Estuarine Coastal Shelf Sci. 50, 673-687.

Muylaert, K., Sabbe, K., Vyverman, W., 2009. Changes in phytoplankton diversity and community composition along the salinity gradient of the Schelde estuary (Belgium/The Netherlands). Estuarine Coastal Shelf Sci. 82, 335-340.

Nielsen, D.L., Brock, M.A., Rees, G.N., Baldwin, D.S., 2003. The effect of increasing salinity on freshwater ecosystems in Australia. Aust. J. Bot. 51, 655-665.

Paerl, H.W., Valdes, L.M., Peierls, B.L., Adolf, J.E., Harding Jr., L.W., 2006. Anthropogenic and climatic influences on the eutrophication of large estuarine ecosystems. Limnol. Oceanogr. 51 (1), 448-462.

Passy, P., Gypens, N., Billen, G., Garnier, J., Thieu, V., Rousseau, V., Callens, J., Parent, J.-Y., Lancelot, C., 2013. A Model reconstruction of riverine nutrient fluxes and eutrophication in the Belgian Coastal Zone since 1984. J. Mar. Syst. 128, 106-122 (this issue).

Peperzak, L., 2002. The wax and wane of Phaeocystis globosa blooms. Ph.D. thesis University of Groninge.

Quinlan, E.L., Philips, E.J., 2007. Phytoplankton assemblages across the marine to lowsalinity transition zone in a blackwater dominated estuary. J. Plankton Res. 29 401-416.
Regnier, P., Steefel, C.I., 1999. A high-resolution estimate of the inorganic nitrogen flux from the Scheldt estuary to the North Sea during a nitrogen-limited algal bloom, spring 1995. Geochim. Cosmochim. Acta 63, 1359-1374.

Regnier, P., Wollast, R., Steefel, C.I., 1997. Long-term fluxes of reactive species in macrotidal estuaries: estimates from a fully transient, multicomponent reactiontransport model. Mar. Chem. 58, 127-145.

Regnier, P., Mouchet, A., Wollast, R., Ronday, F., 1998. A discussion of methods for estimating residual fluxes in strong tidal estuaries. Cont. Shelf Res. 18, 1543-1571.

Roubeix, V., Lancelot, C., 2008. Effect of salinity on growth, cell size and silicification of an euryhaline freshwater diatom Cyclotella Meneghiniana Kutz. Transitional waters. Bulletin 1, 31-38.

Roubeix, V., Rousseau, V., Lancelot, C., 2008. Diatom succession and silicon removal from freshwater in estuarine mixing zones: from experiment to modelling. Estuarine Coastal Shelf Sci. 78, 14-26.

Rousseau, V., Leynaert, A., Daoud, N., Lancelot, C., 2002. Diatom succession, silicification and silicic acid availability in Belgian coastal waters (Southern North Sea). Mar. Ecol. Prog. Ser. 236, 61-73.

Ruelland, D., Billen, G., Brunstein, D., Garnier, J., 2007. SENEQUE: a multi-scaled GIS interface to the RIVERSTRAHLER model of the biogeochemical functioning of river systems. Sci. Total. Environ. 375, 257-273.

Schultz Jr., G.E., Ducklow, H.W., 2000. Changes in bacterioplankton metabolic capabilities along a salinity gradient in the York River estuary, Virginia, USA. Aquat. Microb. Ecol. 22, 163-174.

Soetaert, K., Herman, P.M.J., 1995a. Nitrogen dynamics in the Westerschelde estuary (S.W. Netherlands) estimates by means of the ecosystem model MOSES. Hydrobiologia 311, 225-246.

Soetaert, K., Herman, P.M.J., 1995b. Estimating estuarine residence times in the WesterScheldt (the Netherlands) using a box model with fixed dispersion coefficients. Hydrobiologia 311, 215-224.

Soetaert, K., Middelburg, J.J., Heip, C., Meire, P., Van Damme, S., Maris, T., 2006. Longterm change in dissolved inorganic nutrients in the heterotropic Scheldt estuary (Belgium, The Netherlands). Limnol. Oceanogr. 51, 409-423.

Thieu, V., Garnier, J., Billen, G., 2010. Assessing the effect of nutrient mitigation measures in the watersheds of the Southern Bight of the North Sea. Sci. Total. Environ. 408, 1245-1255.

Thieu, V., Billen, G., Garnier, J., Benoît, M., 2011. Nitrogen cycling in a hypothetical scenario of generalized organic agriculture in the Seine, Somme and Scheldt watersheds. Reg. Environ. Chang. 11 (2), 359-370.

Thouvenot, M., Billen, G., Garnier, J., 2007. Modelling nutrient exchange at the sediment-water interface of River Systems. J. Hydrol. 341, 55-78.

Toro, E.F., 1997. Riemann Solvers and Numerical Methods for Fluid Dynamics. SpringerVerlag, Berlin Heidelberg. 591 pp.

Van Damme, S. Struyf, E. Maris, T. Ysebaert, T. Dehairs, F., Tackx, M. Heip, C. Meire, P. 2005. Spatial and temporal patterns of water quality along the estuarine salinity gradient of the Scheldt estuary (Belgium and The Netherlands): results of an integrated monitoring approach. Hydrobiologia 540, 29-45.

Vanderborght, J.P., Wollast, R., Loijens, M., Regnier, P., 2002. Application of a transportreaction model to the estimation of biogas fluxes in the Scheldt estuary. Biogeochemistry 59, 207-237.

Vanderborght, J.P., Folmer, I., Aguilera, D.R., Uhrenholdt, T., Regnier, P., 2007. Reactivetransport modeling of a river-estuarine-coastal zone system: application to the Scheldt estuary. Mar. Chem. 106, 92-110.

Villars, M., Vos, R., 1999. RESTWES: Remote sensing as a tool for integrated monitoring of the Western Scheldt. Tech. Rep. Z2472. WL/Delft Hydraulics, Delft, Netherlands.

Wollast, R., 1983. Interactions in estuaries and coastal waters. In: Bolin, B., Cook, R.B. (Eds.), The major biogeochemical cycles and their interactions. SCOPE 21 . WileyInterscience, pp. 385-407.

Wollast, R., 1988. The Scheldt estuary. In: Salomons, W., et al. (Ed.), Pollution of the North Sea: An assessment. Springer, pp. 185-193. 